Portland State University

PDXScholar

5-9-1996

\title{
What in God's Name: The Ordination of Women and the Inclusive Language Liturgy Movement
}

Marylee L. Prince

Portland State University

Follow this and additional works at: https://pdxscholar.library.pdx.edu/open_access_etds

Part of the Sociology Commons

Let us know how access to this document benefits you.

\section{Recommended Citation}

Prince, Marylee L., "What in God's Name: The Ordination of Women and the Inclusive Language Liturgy Movement" (1996). Dissertations and Theses. Paper 5148.

https://doi.org/10.15760/etd.7024

This Thesis is brought to you for free and open access. It has been accepted for inclusion in Dissertations and Theses by an authorized administrator of PDXScholar. Please contact us if we can make this document more accessible: pdxscholar@pdx.edu. 
The abstract and thesis of Marylee $L$. Prince for the Master of Science in Sociology were presented May 9, 1996, and accepted by the thesis committee and the department.

COMMITTEE APPROVALS :
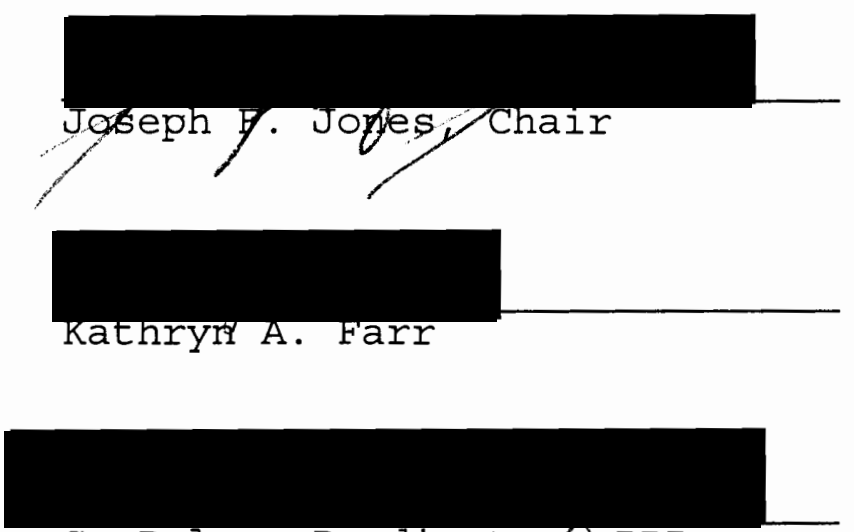

G. Palmer Pardington(J III

DEPARTMENT APPROVAL:
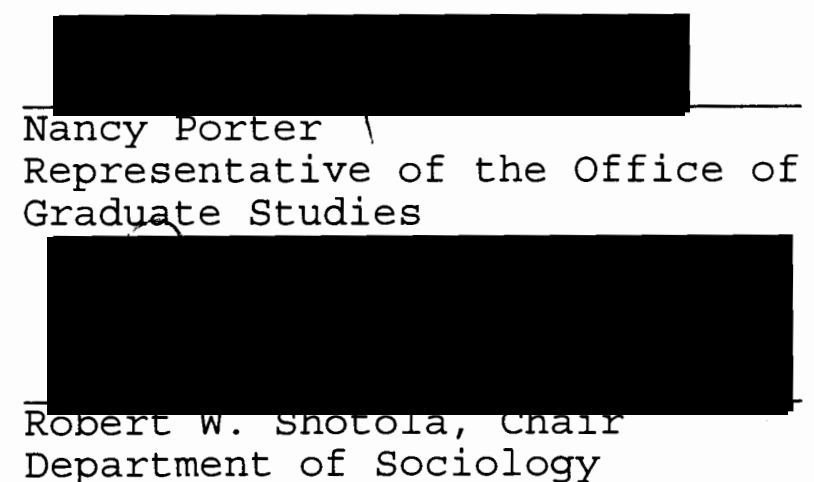

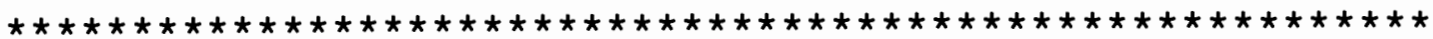

ACCEPTED FOR PORTLAND STATE UNIVERSITY BY THE LIBRARY

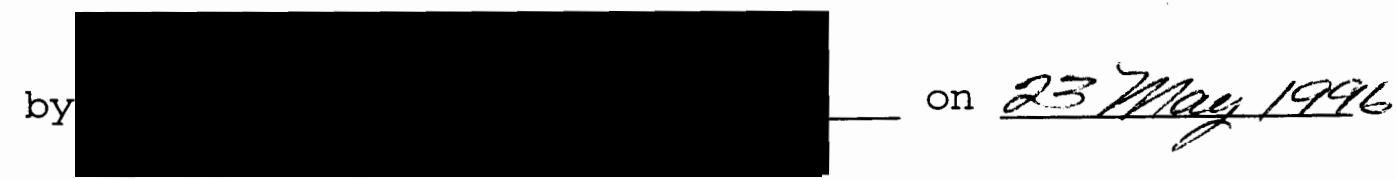




\section{ABSTRACT}

An abstract of the thesis of Marylee L. Prince for the Master of Science in Sociology presented May 9, 1996.

Title: What in God's Name: The Ordination of Women and the Inclusive Language Liturgy Movement

In the years since World War II, increasing numbers of women have been ordained as clergy in mainstream Protestant denominations. During this period there has also been a movement to use inclusive language for God. This study examines the possibility that use of inclusive language for God in communal prayer by congregations in specific denominations (United Methodist Church, United Presbyterian Church USA, Evangelical Lutheran Church in America, United Church of Christ, and the Episcopal Church USA) is related to experience with women clergy.

Interviews, based on a questionnaire developed for this study, were held with the pastors of six Portland area congregations in each of these denominations. The questions were designed to elicit information about each congregation, the clergy associated with each congregation, and the use of inclusive language for God within each congregation.

The results of the study are inconclusive. The United Methodist Church and the United Church of Christ began 
ordaining women many years before the other three denominations did. The two denominations also have produced liturgical materials which use inclusive language for God. However, there did not appear to be a relationship between an individual congregation's experience with women clergy and its use of inclusive language for God in communal prayer. 
WHAT IN GOD'S NAME: THE ORDINATION OF WOMEN AND THE INCLUSIVE LANGUAGE LITURGY MOVEMENT

\author{
by
}

MARYLEE L. PRINCE

\begin{abstract}
A thesis submitted in partial fulfillment of the requirements for the degree of

MASTER OF SCIENCE

in

SOCIOLOGY
\end{abstract}

Portland State University

1996 
LIST OF TABLES.

PAGE

CHAPTER

I

INTRODUCTION. . . . . . . . . . . . . . . . . . 1

Women in the Church . . . . . . . . . . . 2

The Early Years. . . . . . . . . . . 2

Post-Reformation . . . . . . . . . . 5

Early Twentieth Century. . . . . . . 8

1960 s and Beyond.......... . 11

Inclusive Language. . . . . . . . . . . . 17

II THEORY. . . . . . . . . . . . . . . . . . 31

Durkheim and the sacred... . . . . . . 31

Language and Symbol .. . . . . . . . . . 35

Religion and Experience... . . . . . . 37

Symbolic Boundaries... . . . . . . . . 40

Function and Dysfunction. . . . . . . . . 45

Feminism, Religion, and the Historical Moment 47

III METHODOLOGY . . . . . . . . . . . . . . . 51

Introduction. . . . . . . . . . . . . . 51

Population. . . . . . . . . . . . . . . 52

Sample Selection Procedure. . . . . . . 53

The Questionnaire . . . . . . . . . 55

IV DATA. . . . . . . . . . . . . . . . 58

Congregational Questionnaire. . . . . . 58

Demographic Information . . . . . . . . . 59

Summary of Responses to Demographic

Information. . . . . . . . . . . . . 74

Clergy Characteristics. . . . . . . . 75

Summary of Clergy Data. . . . . . . . . . 85

Use of Inclusive Language for God . . . . 87

Summary of Inclusive Language Use Data. . 96

Language and Experience... . . . . . 98

V SUMMARY AND CONCLUSIONS . . . . . . . 100

Areas for Future Research . . . . . . . . 103

Conclusion. . . . .......... . 104

REFERENCES. . . . . . . . . . . . . 105

APPENDIX A. . . . . . . . . . . . . . . . 110 
1 Size of Congregation by Language Use. . . . . . 60

2 Size of Congregation by Experience with Woman Clergy. . . . . . . . . . . . . . . 61

3 Congregation Age Characteristics by Language Use 62

4 Congregation Age Characteristics by Experience with Woman Clergy . . . . . . . . . . . . 63

5 Ethnicity of Congregation by Language Use . . . 64

6 Ethnicity of Congregation by Experience with Woman Clergy. . . . . . . . . . . . . . 64

7 Dominant Education Level of Congregation by Language Use. . . . . . . . . . . . . . . 65

8 Dominant Education Level of Congregation by Experience with Woman Clergy. . . . . . . . 66

9 Congregation Income Type by Language Use. . . . 67

10 Congregation Income Type by Experience with Woman Clergy. . . . . . . . . . . . . . . 68

11 Congregation Income Source by Language Use. . . 69

12 Congregation Income Source by Experience with woman Clergy. . . . . . . . . . . . . . . . . 70

13 Occupation of Congregation Members by Language Use . . . . . . . . . . . . . . . . . . 70

14 Occupation of Congregation Members by Experience with Woman Clergy . . . . . . . . . . . . 71

15 Congregation Change in the last 5-10 years by Language Use. . . . . . . . . . . . . . . . 73

16 Congregation Change in the last 5-10 years by Experience with Woman Clergy. . . . . . . . . 73

17 Number of Paid Clergy on Staff by Language Use. 76

18 Number of Paid Clergy on Staff by Experience with Woman Clergy. . . . . . . . . . . . . . 77

19 Presence of Unpaid Clergy Associated with the Congregation by Language Use. . . . . . . .

20 Presence of Unpaid Clergy Associated with the Congregation by Experience with Woman Clergy.

21 Senior or Sole Pastor's Length of Service in Current Congregation by Language Use. . . .

22 Senior or Sole Pastor's Length of Service in Current Congregation by Experience with Woman Clergy........................ . . . 80

23 Sex of Senior or Sole Pastor by Language Use . . 81

24 Sex of Senior or Sole Pastor by Experience with Woman Clergy. . . . . . . . . . . . . . . . 81

25 Seminary Type of Senior or Sole Pastor by 82

26 Seminary Type of Senior or sole Pastor by 83 Experience with Woman Clergy . . . . . . . 83 
27 Year of Ordination of Senior or Sole Pastor by Language Use . . . . . . . . . . . . . . . . . 84

28 Year of Ordination of Senior or Sole Pastor by

29 Use of Inclusive Language for God in Hymnody by

30 Use of Inclusive Language for God in Hymnody by Experience with Woman Clergy .. . . . . . .

31 Use of Inclusive Language for God in Sermons by Language Use in Prayer . . . . . . . . . . . . 89

32 Use of Inclusive Language for God in Sermons by Experience with Woman Clergy . . . . . . . . . 90

33 Use of Inclusive Language for God in Christian Education Material by Language Use in Prayer.

34 Use of Inclusive Language for God in Christian Education Material by Experience with Woman Clergy . . . . . . . . . . . . . . . . . . . . 91

35 Use of Inclusive Language for God in Prayer by Experience with Woman Clergy . . . . . . . . . 92

36 Intent to Change Use of Inclusive Language for God in Prayer by Language Use. . . . . . . . . 93

37 Intent to Change Use of Inclusive Language for God in Prayer by Experience with Woman Clergy. 94

38 Decision to Use Inclusive Language for God in Prayer by Language Use . . . . . . . . . . . . 95

39 Decision to Use Inclusive Language for God in Prayer by Experience with Woman Clergy . . . . 96 
CHAPTER ONE

INTRODUCTION

Sexuality and related gender issues have become hot topics in Christian churches at the end of the twentieth century. Across denominations, the same issues homosexuality, reproduction, women's ordination, and inclusive language - emerge. The ordination of women and inclusive liturgical language are the subject of this inquiry. Specifically, an attempt is made to determine if the movement toward the use of inclusive language in liturgy in mainstream Protestant denominations is the result of changing religious roles for women (specifically, ordination) or if women's ordination and the liturgical movement both reflect larger social changes.

Although some denominations of Protestant Christians in the United States have been ordaining women for more than a century, it has only been since the 1960s and $1970 \mathrm{~s}$ that significant numbers of women have been ordained by the mainstream denominations. In the years that have followed, there has also been a movement away from the exclusive use of masculine names and imagery for the divine and toward the use of more inclusive language and imagery. A brief tracing of the history of women in ordained ministry will provide background for these 
shifts. Following this, a definition of inclusive language in the liturgical setting and a description of changes taking place there provides the background for the present research.

(Several of the denominations in this study call their ordained persons "ministers." The Episcopal Church uses the term "priest." In order to reduce redundancy and confusion, the term pastor will be used to refer to ordained persons, be they priests or ministers.)

WOMEN IN THE CHURCH

The Early Years

In his 22 May 1994 pastoral letter, Ordinatio Sacerdotalis, Pope John Paul II summarized the traditional view of women in ordained ministry by stating that the priesthood must be limited to men because Jesus chose only men to be his apostles and it was only to those men that Jesus revealed himself after the resurrection. One of the bitingly humorous stories circulating in response to this states that, since Jesus chose only married, Greekspeaking, Jewish men, the Pope is ineligible to be Pope and must resign until he marries, learns Greek, converts to Judaism and back to Catholicism.

On a more serious level, the pope seemed to be overlooking the fact that all four gospels clearly state 
that Mary Magdalene was the first person to witness the resurrection (Matthew 28:9, Mark 16:9, Luke 24:10, John 20:16). This fact is a cornerstone on which feminist theologians, Biblical historians, and other proponents of women's ordination build their case.

Women have played a significant role at many times during Christian history, beginning even before Jesus's death. It was by a woman that he was first recognized as Messiah (John 4:25-26). It was a woman who pushed the boundaries of his ministry outside the Jewish community to include gentiles (Matthew 15:21, Mark 7:24-30). As noted, the Gospels name Mary Magdalene as the first witness to the resurrection.

The Epistles make reference to various churches meeting in women's homes. Feminist biblical scholarship is filled with evidence that first century Christianity was led by both men and women. New Testament scholar Elisabeth Schussler Fiorenza, for example, believes that in the Gospel of Mark,

the women disciples are the functional successors of Jesus and they continue Jesus' mission and ministry in the "New Family" of God. Far from being exemplars of apostolic discipleship, the Twelve are the negative blueprint of right discipleship (1992:17).

When the Emperor Constantine established Christianity as the official religion of the Roman Empire in 323 Christian Era (CE), Christian men were able to assume 
institutional power. Women were pushed to the margins of the church, but were allowed to form religious communities.

By this time the worship of Mary was widespread. Male church leaders tried to stop it and were unable to do so. Epiphanius wrote a book, Panarion, in $377 \mathrm{CE}$ which gave detailed descriptions of all the current heresies. Heresy number 79 describes a group called Collyridans, a group of women from the area which ranged from the shores of the Black Sea to Egypt. These women worshipped Mary as Queen of Heaven, her rites and attributes appearing very much like those of earlier female deities (Ashe, 1988).

Christianity is, after all, a syncretic religion and consciously co-opted local customs, giving them an "orthodox" overlay. Stories, legends, and shrines belonging to many of the earlier goddesses were attributed to Mary (Ashe, 1988). Other local deities, both male and female, seem to have become the panoply of saints (Ashe, 1988).

Another characteristic of Christianity is that it undergoes periodic bouts of reform, which seem to coincide with periods of widespread social change. Probably the best known of these is the Protestant Reformation of the sixteenth century. 


\section{Post-Reformation}

During times of pronounced social change, women have been more included in official roles than during more stable periods. In fact, there is an association between women in ministry and social revolution. At the time of the Reformation, the more radical sects (for example, the Anabaptists) had. women ministers (Field-Bibb, 1991). Since that time the pentecostal movements, relying as they do on the action of the Holy Spirit rather than established traditions, have continued to have women leaders.

In the eighteenth century, Anglican priests Charles and Samuel Wesley began the reform movement which resulted in the denomination currently known as Methodist. Working alongside them was their mother Suzannah. The movement spread to the American frontier. In 1829 a Primitive Methodist group ordained a woman, the first recorded instance of such an act in the United States (Melton, 1991).

Presbyterian women formed The Female Charitable Society at the First Presbyterian Church of Newark, New Jersey, in 1803 (Verdesi, 1976:39). This was but one of many such groups springing up in all denominations across the country at the time. Their purpose was to aid the work of "(1) the pioneer Sunday school workers on the frontier; (2) 'pious and indigent' ministerial students; and (3) 
missionaries" (Verdesi, 1976:39-40).

By mid-century, many of these groups were working for the abolition of slavery. As they worked for the freedom of others, many women in the movement became aware that they did not have the rights they were trying to get for the slaves. Abolition activists Lucretia Mott and Elizabeth Cady Stanton attended the world Anti-Slavery Convention in London in 1840. The convention refused to seat them as delegates (Verdesi, 1976:41). Stanton spent the remainder of her life working for women's rights, including the right to be ordained.

In 1872 an action of the Presbyterian General Assembly approved a measure which "shall forbid the licensing and ordaining of women to the gospel ministry" (Verdesi, 1976:25). A Presbyterian minister, the Rev. George P. Hays, published a Bible-study pamphlet in 1889 entitled May Women Speak? In it he attempted to demonstrate that st. Paul's admonition against women's speaking in church was directed against two specific women and not against women in general. He then proceeded to question the fact that the Presbyterian church was willing to make exceptions to ordination rules for men but not for women, noting that

God's blessing and success can make up for every other defect; but if a person's gender is wrong, no endorsement of the Holy Ghost and no favor of Christian people can atone for that in the eyes of 
the Presbyterian Church; nor indeed in any other evangelical church except the Quakers (quoted in Verdesi, 1976:44).

The death of so many young men during the Civil war contributed to women's professional activities during the second portion of the nineteenth century. This was accentuated by the conscious effort in many frontier communities to break away from the traditional social patterns the pioneers had left behind. "Female doctors, dentists, and lawyers who could not get licensed back East were given a hearty welcome in the frontier communities" (Tucker, 1990:4). Women clergy were often welcomed as well.

1895 was a landmark year for Christian feminists, witnessing the publication of The Woman's Bible, a first attempt (in English, at least) at Biblical scholarship by women. Ironically, it grew out of the injunction of Church Fathers that women challenging the traditional role of women in church and society should look to the Bible to see what it said about women's place in creation. With Elizabeth Cady Stanton as leader, a group of women calling themselves the Revising Committee did just that. What they found was that the Bible itself can be interpreted in several ways.

The 1974 edition of The Women's Bible opens with a copy of a note in stanton's handwriting which says, 
"Genesis Chapter I says Man and Woman were a simultaneous creation. Chapter II says Woman was an afterthought. Which is true?" Bible readers still struggle with the issue 100 years later.

\section{Early Twentieth Century}

The 1890s and early years of the twentieth century saw the rise of two religious groups founded and administered by women - Christian Science by Mary Baker Eddy and the Foursquare Church of Amy Semple McPherson. Additionally, there were five ordained Unitarian women in 1870, the number growing slowly for the remainder of the century. In Iowa during the 1880s and $1890 \mathrm{~s}$ a small group of ordained Unitarian women with successful frontier ministries began working together for mutual support.

By the end of the century, however, the feeling among Unitarian leaders was that the ministry should be "masculinized." The frontier women left parish ministry and turned their energies to social movements such as settlement houses and women's suffrage. The denomination continued to ordain women while making it difficult for them to have positions in congregations (Tucker, 1990:5).

An attempt to be ordained to ministry in the Presbyterian Church involved a "Miss Rachel Gleason Brooks" and the Presbytery of Chemung in Central New York. 
After much discussion which took place during several days running, the presbytery voted 11 to 10 to "take Miss...Brooks under its care as a student in theology" (quoted in Verdesi, 1976:91). Miss Brooks is not mentioned again in the minutes of that presbytery.

North Church in Elmira, New York, arranged for a Mrs. Lillian Herrick Chapman to serve as their preacher while their pastor was in France during World War I. This was approved by the Presbytery of Chemung in september 1918 . The Rev. Robert $C$. Hallock (the lone vote against her serving) filed a formal complaint with the synod of New York on the grounds that this action was "(1) irregular; (2) unconstitutional; (3) unscriptural" (Verdesi, $1976: 92)$.

The synod failed to have its regular meeting because of the flu pandemic so Dr. Hallock appealed to the General Assembly. The General Assembly referred it back to the Synod. In October, 1919, the synod appointed a judicial commission which ordered the license withdrawn. It further instructed the presbytery to use the normal procedures for securing constitutional change. The synod of New York "declined to act in the case of Mrs. Chapman" (Verdesi, 1976:94). In 1920 Mrs. Chapman returned her license to the presbytery.

In 1920 the Presbyterian General Assembly called a 
Special Commission of the Official Relation of Women in the Church. During their work they discovered that nearly all other denominations admitted women to any position except the ministry... more than half the ministers favored ordination of women as ruling elders, and more than half the women [on the commission] were in favor of ordaining women both as elders and as ministers (Verdesi, 1976:95).

The 1927 study by the Federal Council of the Churches of Christ in America reported that only seven of 22 denominations, representing well over half the Protestant church membership in the United States, gave women equal status with men. Among the seven were the Congregationalists. Those not ordaining women included the Presbyterians, United Lutherans, several Methodist groups, and the Episcopalians. Furthermore, the Presbyterian groups and the Episcopal Church did not even permit representation of women on church councils (Verdesi, $1976: 95)$.

The Depression years saw increased activity of women in the area of Christian education. Professional standards were established which included seminary education. These led to the development of positions which held commissioned church worker status, which was similar to, but not the equivalent of, ordination.

World War II witnessed a resurgence of women's demands to be ordained. In the United States, the absence of men allowed women to expand their areas of 
responsibility in the church as well as in the workplace. A shortage of qualified Christian educators combined with the reduced number of men graduating from seminary during the war years led the United Presbyterian Church to develop an active recruitment program. The program was clearly aimed at recruiting boys for ministry. Any girl who responded was encouraged to consider Christian education (Verdesi, 1976:129).

When the men returned from war, there was a general feeling that working women should quit their jobs so that the returning servicemen could go to work. However, not everyone thought the women needed to relinquish their new roles.

\section{0 s and Beyond}

A Gallup Poll found in May of 1947 that $43 \%$ of the respondents thought a woman would make as a good a minister as a man (Wuthnow, 1988:224). A conference held in 1951 to consider "Women and the Church" reported that secular culture, with its admittance of women on an equal basis into most walks of life, has advanced far beyond the church community (quoted in Verdesi, $1976: 32$ ).

By the mid-1950s there were movements to ordain women in all the mainstream Protestant groups covered by this study, except of course, the ones who were already ordaining women. 
The United Presbyterian Church approved women's ordination to the ministry in 1956 (Verdesi, 1976:25). However, it was not until 1970 that the denomination began counting women clergy separately, so accurate numbers are difficult to find.

In 1964, the World Council of Churches published a document, "Concerning the Ordination of Women." In a survey of 168 member churches, it was found that 48 admitted women to full [ordained] ministry, and 9 to partial or occasional ministry; 90 did not admit women to any ministry, and 21 made no reply. By 1970, there were 72 member churches which ordained women and 143 which did not. The majority of those ordaining were in the West. The Eastern European churches were in the middle and the lowest incidence was in Asia, Africa, and Latin America (Field-Bibb, 1991).

North American denominations, listed as ordaining women in The World Council of Churches 1970 report, included both Canadian and American denominations. Those included as ordaining were Baptists, Disciples, Lutheran, Methodist, Reformed, and United. Lutherans in Sweden began discussing women's ordination in the 1920s, finally approving it in 1960. Danish Lutherans began ordaining women in 1947. The Lutheran Church in America, one of the bodies in the 1985 merger which formed the Evangelical 
Lutheran Church in America, began ordaining women in 1970.

The Methodist Church in England, Scotland, and wales had women's ordination as an agenda item 34 times in 45 years, beginning in the 1920s. Apparently both proponents and opponents were determined to see their position win. The Baptist Union of Great Britain and Ireland began ordaining women in 1918. The Congregation Union of England and Wales began in 1917. Presbyterians in England did so in 1921, but it wasn't until 1965 that the Church of Scotland approved it (Howard, 1972:60-61).

Two retired bishops of the Episcopal church joined with a bishop who had resigned to force the issue for their denomination in 1974 by "irregularly" ordaining eleven women in Philadelphia. Four more were ordained by another resigned bishop in Washington, D.C. the following year. The 1976 General Convention of the Episcopal Church engaged in heated discussion before voting to admit women to the priesthood.

In 1985, Edward Lehman published a study of women in the clergy, focussing on the United Presbyterian Church lone of the groups which merged in 1983 to form the Presbyterian Church USA). He saw the presence of women clergy as part of the general change in the world of work related to the opening of traditional male roles by $\mathrm{Title}$ VII of the United States' Civil Rights Act of 1964, even 
though Title VII does not apply to churches because of the separation of church and state.

Between 1972 and 1980, there was a significant (241\%) increase in the number of women in all denominations enrolled in ordination tracks at the same time that the number of men decreased (Lehman, 1985), growing from $10.2 \%$ of the total seminary student population to $29.6 \%$ in 1990 (Yearbook of American and Canadian Churches, 1995:280). The percentage of women seminary faculty grew also, from $2.8 \%$ in 1970 to $19.7 \%$ in 1993 . At the seminary executive level, however, there were still no women in 1993 (Yearbook, 1995:280).

The increased presence of women, coupled with the decrease in the number of men, resulted in changes in the seminary curriculum. This began to take place as the women students banded together in support groups. These groups

successfully linked the desire for eliminating sexist elements in traditional church life with basic Christian concepts of justice, love and equality before god [sic]. To be sure, the ideological linkages were obvious once pointed out. The denominational hierarchies virtually had to respond to the women's demands in good faith. As a result, today there is movement toward a variety of reforms, i.e., ordination of clergy women, liturgical change, modifications of church literature and church school curricula, new Biblical translations and interpretations, hymnals without sexist language, etc. (Lehman, 1985:16).

In his 1971 discussion of the ministry of women, Peter Brunner felt that no particular form of church 
structure can be "Biblically or legalistically maintained for all time" (Brunner, 1971:15). He includes in a footnote a quote from a Fr. Zerbst, who recognized the importance of having the church's message be consistent with its practice. Fr. Zerbst stated

The church cannot allow its ministers to contradict the content of their messages by their personal lives. Therefore she [the church] demands from each member of the body of christ conduct in keeping with His Word. In regard to the calling of women to the ministry, it must be carefully considered whether entrusting the woman with the proclamation of the Gospel and the administration of the sacraments does not cancel out the proclamation of the church concerning her position according to the creation. First of all, it is decisive for our problem to discover what the church as such teaches about the position of the woman and then whether this doctrine must not also find expression in the ordering of the church's ministries (Brunner, 1971:15).

It is precisely such teaching about the role of women that feminist Biblical scholars, linguists, ministers, and theologians are challenging. One of these challenges occurred in Minneapolis, Minnesota at the 1993 REimagining Conference whose purpose was to explore new language and images for God.

In 1989 one woman, the Rev. Sally Hill, gathered an ecumenical group of women to explore the possibility of getting involved in the Ecumenical Decade of Churches in Solidarity with Women. The group grew to include 140 volunteers, with funding from 23 agencies and 24 
individuals, who put on a four-day conference in November of 1993. The conference featured 35 women presenters and was attended by 2200 people (including 83 men) from 49 states and 27 counties, representing 32 Christian denominations. Thirteen hundred people were turned away (RE-imagining, 1993:1). One male participant who spent five months on the waiting list was overhead saying, "It never occurred to me that something the church was doing would sell out."

By December, 1993, the Christian press was printing articles and letters from outraged members of the religious right, claiming that the conference had featured goddess worship and denigration of traditional Christian beliefs. Particularly under fire were the Presbyterian Church USA (PCUSA) and the United Methodist Church (UMC), which had provided grant money and had made it possible for some of their staff members to participate in the planning of the conference. In addition, both the PCUSA and the UMC had paid the way for additional denomination staff to attend it.

By early spring, articles on the conference, both in favor and against, had appeared in mainstream publications such as Christianity Today and The New York Times. By June, 1994, national conferences of the UMC and the PCUSA had discussed the allegations. Mary Ann Landry, a staff 
person with PCUSA, lost her job because of her role in the conference.

\section{INCLUSIVE LANGUAGE}

Inclusive language, as used in religious contexts, can be divided into two main categories - language used for people and language used for God. The focus here is on inclusive language as it is used for God. While the intent is to address inclusive language for God as a generality which includes all of the several methods by which inclusivity is typically approached, it will be helpful to describe them.

The first type is language which becomes inclusive by avoiding gender. Typically, this involves eliminating pronouns. Thus, the psalm passage, "Give thanks to God for he is good. His mercy endures forever" becomes "Give thanks to God for God is good. God's mercy endures forever." This can result in writing which is repetitive and awkward. On the other hand, it is the form of being inclusive which creates the least amount of resistance. A theological result is that it tends to make God an impersonal thing - Ground of Being, Source - rather than a personality with whom relationship is possible.

The second type is to keep the familiar masculine language and to balance it by including biblical, feminine 
imagery for God, a "divine androgyny" (Noren, 1991:121). Carter Heyward invoked a prayer to "the Holy one of Israel, whom Jesus called abba (daddy) and who in truth, is also the Mother of us all" (Noren, 1991:121).

Similar to this is the introduction of ungendered images and descriptions. Resource material published by the United Methodist Church includes a wide variety of non-traditional, yet Biblical images. Among them are "Awesome One, Binder of Wounds, Existence Itself, Shelter from the Storm" (Noren, 1991:121). These share the problem of relationship to the extent that they can be attributes of things rather than of someone with whom a believer would seek relationship.

Another variety is to see God as relationship rather than thing. This move away from traditional language introduces a new concept of experience in which the focus is on interpersonal and intrapersonal concerns. An example from Rosemary Radford Ruether includes this passage, "We are the new wine of life that flows in the branches of the vinetree. We remember our brother Jesus...." (Noren, 1991:121).

Finally, there is a school which views God as a verb. Carter Heyward uses the term "godding." Rita Nakashimi Brock discusses the immanent aspect of God as verb, action, rather than thing. Immanence is well documented as 
part of God's nature (see Models of God, by Sallie McFague, for example) and is probably best described in Christian terms as what the Holy spirit does. It is, however, somewhat more difficult to relate oneself to action than to a person or even to a thing.

As mentioned above, the present attempt is not to distinguish between the ways in which the various types of inclusive language (and imagery) are being used. Rather, it will be "inclusive" of all ways of talking about/imaging God.

The controversy over inclusive language and imagery for God became even more heated after the previously mentioned RE-Imagining Conference held in Minnesota in the fall of 1993. In her address to the conference, Mary Hunt called sex "the playing field in a violent world" (Hunt, 1993) where gender related issues are used to obscure abuses of power. While some might wince at her description of liturgical inclusive language as the "castration of the bible" (Hunt, 1993), there is not any doubt that it touches on the basic understanding people have of God and challenges their fifth-grade Sunday School theology.

The dominant teaching of most denominations is that the Christian God is male - a father, a son, and a holy spirit who carries a masculine pronoun. Most creditable theologians will agree that this is imagery, an attempt to 
describe the undescribable, and that the God of Creation is beyond anthropomorphized gender. "How hard it is to find the right [words]" (Altizer and Hamilton, 1966:35). Few, however, carry their understanding of who/what this God is into the language of communal prayer.

It is the language used for God in communal prayer that is at the center of the current controversy. "The operative feature of religion consists less of the moods generated...than of its all-encompassing vision of reality" (Wuthnow, 1988:474). That is to say, the words which a group of people use for its God reflect and reinforce the group's understanding of its place in the social, physical and spiritual universe. The words create the matrix by which both God and the group's relationship to God are defined because

religious ideas and religious values are in part influenced by the social groups among whom they originate; they express the needs, the thought-ways, the perspectives upon the world of such social strata. But once they become established as elements of the culture and are taught as the belief system of a religion, they have a formative influence upon the values and motivations of men [sic]. Thus religion is both affected by, and affects, social conditions. It can be either cause or effect ( $O^{\prime}$ Dea and $O^{\prime}$ DeaAviad, 1982:95).

Until the 1960s, mainstream Protestant church services were characterized by male clergy praying to a male God, even though the pews on Sunday morning were likely to filled with females. The Civil Rights and equal- 
rights-feminist movements of the 1960 s and 1970 s led to changes in the language used for human beings, but not in that used for God At the same time, attendance at worship services began to decline. Few church leaders seemed to consider the possibility that there might be a connection between attendance and language.

The social change movements also resulted in a move toward the inclusion of language and imagery for humans which was meaningful to people who were not middle-class white males. The "he or she" construction dates from this period. Church hymnals were reworked to reflect social change. Many added songs in Spanish as well as other languages, and from the African-American traditions. Christian education material began to include pictures and stories of people of color, of people with physical disabilities, of women doing non-traditional tasks, of groups of people from various socio-economic and cultural backgrounds working together.

In 1968 a Roman Catholic woman, Mary Daly, published a book entitled The Church and the second Sex. She summed up the experience of many women on the first page of Chapter One:

Proponents of equality charge that there is inexcusable hypocrisy in a species of ecclesiastical propaganda which pretends to put woman on a pedestal but which in reality prevents her from genuine selffulfillment and from active adult-size participation in society (Daly, 1968:11). 
Daly has since left the church to become a postchristian ecofeminist, but that publication and her 1973 work, Beyond God the Father, stand as watershed markers and have been followed by the scholarly work of record numbers of seminary-trained women who were seriously challenging existing religious systems. This work resulted in the development of feminist theology, a basic tenet of which is that God includes the feminine and, thus, the traditional language for God is inadequate and needs to be changed.

In the ensuing struggle, the idea that the masculine is generic is encountered once again. People who had long been convinced that masculine pronouns did not refer to women found themselves resistant to thinking of God as "she."

In her discussion of patriarchal theology, feminist theologian Rosemary Radford Ruether (1985) claims that the male is seen as the norm for both the human species and for imaging God. Two examples can be found in the ancient Greek texts, the Te Deum and the Athanasian Creed, where the words homo (human) and humanitas (humanity) are used to describe the Christ and are translated as man and manhood in the official English texts (General Synod, 1972). Ruether goes on to say that in Christian patriarchal theology, the experience of white male 
Christians is assumed to be the experience of all humanity.

The idea that the masculine takes precedence is a relatively recent development in the English language. In 1553 it was suggested that the male should precede the female, but it was not until 1850 that an Act of the English Parliament declared that the word "he" would stand for the word "she" (Grant, 1994). However, the inclusion of the feminine in the masculine is not absolute. Rather, the masculine includes the feminine when there are penalties and does not include it when there are privileges (Grant, 1993). Women have been jailed for breaking laws which were written using masculine pronouns (an example of penalty) and forbidden entrance to professions (privilege) because of language which used masculine pronouns. It is probably safe to assume that the traditional [male] theologians perceive the masculinity of God as privilege rather than as penalty.

One of the arguments used against ordaining women was that the minister stands as the representative of Jesus and, thus, needs to be male as he had been. Tongue-incheek critics of this position pointed out that, to be accurately representative, the ministry would need to be limited to young, Jewish, male fishermen who must either resign or be crucified when they reach the age of 35 . 
What began to happen as women appeared in the pulpit was an awakening of women's experience of exclusion from their religious tradition. In 1975, one woman described her experience in a letter to Carter Heyward, one of the "irregularly" ordained Episcopal women. The letter was written after the woman had participated in an Episcopal worship service which Heyward conducted. The event was the woman writer's first experience with women clergy and she said

I did not expect to be so personally affected by your presence here. I was unaware of the ways that I have felt excluded from God's inner circle of love until I experienced being included--both by the obvious fact of your inclusion and by you, as God's representative, including me. Somehow I feel I've spent my life trying to be God's son, only to realize at last that I am God's daughter (Heyward, 1984:6, italics added by Heyward).

Author Marie Louise Uhr, writing as part of the Movement to Ordain Women (MOW) in Australia, traces the development of the idea of God as Father to erroneous ideas of biology. Primitive people, she says, believed that the sperm contained a tiny human that was merely nourished once planted in the womb. She credits the discovery of DNA with recognizing that both biological parents contribute to the make-up of the new life. Thus, imaging God as father and leaving out the mothering aspect, makes God incomplete.

Mother as an image for God is also problematic, not 
only because of the way the term raises theological blood pressure. Many women are not mothers and feel the term "mother" for God creates a norm for human life that excludes them. Others reject the use of any anthropocentric language for God because it creates God in the image of humans rather than the Biblical reverse.

Language is important because it affects the way we think.

Language combines the functions of a mirror, a tool, and a weapon. In a very real sense, it does reflect society. Indeed, some scholars suggest that all relationships are essentially linguistic, because it is through language that people come to understand not only their similarities, differences, and roles but social reality itself (McConnell-Ginet, $1989: 108$ ).

Experience can only be expressed through the symbols which are available. When experience and reality are in disjunction, new symbols are created. The conscious creation of symbols is an act of altering the collective experience of reality. The new symbols will not be accepted, however, unless others are able to make the connection between the symbol and reality.

Peter Berger and Thomas Luckmann, in their work, The Social Construction of Reality, describe the process by which language interacts with experience. A portion of this process is that language is gathered into bodies of knowledge which become autonomous. As individual people mature, they acquire not only the commonly held knowledge 
systems of their society, they are also initiated into a variety of subsystems of knowledge. Once initiated, they begin to see the world in terms of their subsystem. A geologist, for example, will see a reality which is quite different from the reality of a computer engineer. Each group sees its own reality as inevitable.

Subsystem language groups also isolate themselves from each other to some extent in order to protect members from the "heretical" ideas they might gain from contact with non-initiates. The presence of "heretics" in significant numbers can threaten the belief that one's own definition of reality is inevitable.

Historically, the problem of heresy has often been the first impetus for the systematic theoretical conceptualization of symbolic universes. The development of Christian theological thought as a result of a series of heretical challenges to the "official" tradition provides excellent historical illustrations for this process (Berger and Luckmann, $1966: 99)$.

Sub-universes of meaning only exist, however, in concrete, living human beings. It is the nature of human life that these concrete human beings eventually cease to live and are replaced by other concrete, living human beings. These new living beings do not have experiences which are exactly identical with those of the ones who preceded them.

When such a person has an experience of God and attempts to recreate it by sharing it with others, the 
person must do so by using relevant, already existing symbols from that person's sub-universe. The symbols' meanings can be expanded beyond present meaning, but not divorced from it.

The meanings of symbols can shift with the passage of time. An example of such a shift is the relatively recent change in the meaning of the word "gay." The shift can then result in another disjunctive experience, causing the process to repeat itself.

Religious symbols die when the cultural situation that supported them ceases to give them plausibility. This should pose no problem to authentic faith, which accepts the relativity of all symbols and recognizes that fixation upon any of them as absolute in itself is idolatrous (Daly, 1971:8).

Robert Wuthnow discussed the relationship between the social setting of an idea and the development of that idea. Referring to this as the problem of articulation, he stated,

if cultural products [ideas] do not articulate closely enough with their social settings, they are likely to be regarded by the potential audiences of which these settings are composed as irrelevant, unrealistic, artificial, and overly abstract... but if [they] articulate to closely... they are likely to be though of as esoteric, parochial, time bound, and fail to attract a wider and more lasting audience.... The problem of articulation is particularly enigmatic in the case of discourse that specifically challenges the status quo $(1989: 3)$.

Social change which has taken place during the twentieth century may be affecting the articulation of the 
term "father." For approximately half the children in the United States, "father" is somebody who is absent rather than someone providing stability, caring, or the basic needs of life. While fathers of previous generations have been absent (often for extended periods of time) because of work commitments or in a psychological sense, the growing percentage of homes headed by single women is a fairly recent phenomenon, as is the large number of "deadbeat dads" who are not providing even minimal financial support for their own children.

The first children of the divorced generation are now into their twenties and early thirties and parents themselves. Because these are the children who grew up with working (thus absent) mothers, the parenting images of earlier generations may no longer have the same meanings. There is ample evidence that children's primary bonding is still with their mothers (see the work of Carol Gilligan, for example). However, emotional attachment may differ from role expectation.

The high rate of child abuse may also affect the meaning of the word "father." A 1988 estimate by the National Center for Child Abuse and Neglect indicates that 1.5 million children are physically abused each year in the United States. Other studies suggest that approximately $28 \%$ of adult women and $16 \%$ of adult men were 
sexually abused as children (Wolfe, Sas, and Wekerle, 1994:3). The most common perpetrator of either physical or sexual abuse is a family member or someone the child knows well (Warner and Hansen, 1994:11). Therefore, it should come as no surprise that some people are resisting the idea of God as either father or mother.

During periods of social change, of which the increased reporting of child abuse is an example, conflicting views of reality come into contact with each other. Such contact results in conflict because humans typically can only accept one view of reality as being "the Truth." The fact that increasing numbers of people are reporting child abuse indicates that the old "truth" about fathers having the right to beat their wives and children, for example, is being challenged by a new "truth" in which they no longer have this right.

Berger and Luckmann see two possible ways of alleviating the conflict between truths. One way is through violence - "the fire and the sword." The alternative, "particularly if fire and sword turn out to be unavailable" (or the holders of the competing system are more powerful) is to enter into negotiations with those holding competing views of reality. (Berger and Luckmann, 1966:113).

As feminists agitate for new language to reflect 
their experiences, traditionalists struggle to eliminate this conflicting view of reality. This should result in modification of the tradition (Berger and Luckmann, 1966:99). The process promises to be less than peaceful.

Perhaps Durkheim was being prophetic in 1915 when he wrote

A day will come when our societies will know again those hours of creative effervescence, in the course of which new ideas arise and new formulae are found which serve for a while as a guide to humanity; and when these hours shall have been passed through once, men [sic] will spontaneously feel the need of reliving them from time to time (1915:475). 
CHAPTER TWO

THEORY

Religion as a social phenomenon has been studied by many people, including sociologists Emile Durkheim, Peter Berger, Thomas Luckmann, Robert Wuthnow, and Andrew Greeley. By comparing selected portions of their writings and establishing relevant vocabulary, the relationship between language and group processes may become more clearly understood.

DURKHEIM AND THE SACRED

From his anthropological examination of tribal religion, Emile Durkheim (The Elementary Forms of the Religious Life, 1915) developed the idea that a group of people's concept of personified supernatural beings develops directly from the model provided by that group's social system. The supernatural is that which is not natural, that is to say, not part of every day experience. It is one of those things everyone seems to know exists, but nobody can describe or explain, those things and events which simply do not fit into the everyday world. These are gathered into the same category and are called sacred. There is also an element of numinousness about 
them, that is to say, something beyond, outside of the ordinary.

The supernatural/sacred has two forms which distinguish it from the every day. The first is "mana" which, in the words of Guy Swanson, is the "substance or essence which gives one the ability to perform tasks or achieve ends otherwise impossible" (Swanson, 1974:16).

Access to mana is acquired through activities such as fasting and prayer and through the use of ritual objects. Once acquired, it may be used either for one's own purposes or for those of the group. Furthermore, it must be "infused with human intentions or the intentions of the spirits before its potentialities are realized" (Swanson, $1974: 7)$.

The second form of the supernatural is spirits. These are personified beings which have both intention and purpose. The spirits can influence human life if they want to. It may be believed that the infusion necessary for mana to be realized comes from the spirits. In order to get it, one must engage the assistance of the appropriate spirits. This is done by performing the prescribed ritual action.

That beliefs about the sacred/supernatural persist over time indicates that this translation of non-everyday experience also persists over time. Were this not the 
case, these beliefs would be expected to disappear.

Religion is essentially a social experience and the language and imagery people use for what is called religious expression also develop from their experience. The process begins when an individual has an encounter with the supernatural and wants to share that experience. The sharer is limited to the existing vocabulary of what Durkheim called "intellectual conceptions." This sharing is accomplished through the creation of rituals by which it is re-enacted. In the process, the concepts and the ritual become interconnected. While, technically, the ritual develops from the belief, the myth surrounding the belief is frequently based on the ritual, especially as time passes and the reason for the ritual is no longer obvious.

The religious symbols are the means by which any group affirms itself and which allows it to continue as a group. One of the symbols associated with the ritual, the totem, begins to represent the people sharing the ritual.

It becomes the name and the emblem of the group.

The totem is before all a symbol, a material expression of something else.... In the first place, it is the outward and visible form of...the totemic principle or god. But it is also the symbol of the determined society called the clan. It is its flag; it is the sign by which each clan distinguishes itself from the others.... So if it is at once the symbol of the god and of the society, is that not because the god and the society are only one? (Durkheim, 1915:236) 
The totem is used in religious ritual to represent both the clan and the god. Often this representation takes the form of costuming the ritual leader to appear like the totem. This visual representation then reinforces the connection between god and clan.

The physical image of the totem also serves as a concrete, rather than abstract, item on which the group can focus. This is important because

A single preoccupation cannot posses a group of men [sic]... without being externalized in a material form.... This is why, even in religions very far removed from those we have been studying, the worshippers, when assembled to ask their gods for some event which they ardently desire, are forced to figure it (Durkheim, 1915:401).

Guy Swanson identified three shortcomings in Durkheim's work. First is that the process by which spirits are personified is not discussed. Next is that the society which is venerated is not described. Third, he does not explain why all spirits are not venerated. Swanson concludes that "some experiences with others generate the idea of the supernatural and the two forms: mana and spirits" (Swanson, 1974:17).

In order to address these concerns, Swanson proposes the idea of "constitutional arrangements." These arrangements "may or may not be self-conscious and symbolized in the experience of the participants" (Swanson, 1974:23). The arrangements or structures are 
often conceptualized as supernatural beings. Religion, he states, is the performance of behavior intended to influence these beings.

Swanson also found that when there are important ongoing conflicts among members which cannot be justly solved in an acceptable way, social integration is weakened. Maintaining social integration is one of the functions of religion.

\section{LANGUAGE AND SYMBOL}

Peter Berger and Thomas Luckmann describe religion, along with philosophy, art, and science as "immense edifices of symbolic representations that appear to tower over the reality of everyday life like gigantic presences from another world" (1966:38). Religion, then, is one form of symbol system, built on the most basic symbol system language.

Developing from the dialectic relationship between human biology and human need to produce social order, language is the means by which humans communicate subjective experiences to each other. Language has several characteristics. One is reciprocity. In a conversation, "as I objectivate my own being by means of language, my own being becomes ...continuously available to myself at the same time that it is so available to [the other]" 
(Berger and Luckmann, 1966:36). The process occurs simultaneously in each participant of a conversation.

Another characteristic is that language develops from and is rooted in the experiences of everyday life. This gives it an objective quality. Objective language is external to the speaker and forces the speaker to conform to certain patterns, such as vocabulary and syntax, in order for verbal communication to take place.

Language can also transcend the everyday. It is capable of "'making present' a variety of objects that are spatially, temporally and socially absent from the 'here and now'" (Berger and Luckmann, 1966:37). Language can also construct "symbols that are highly abstracted from everyday experience" and bring them back as "objectively real elements in everyday life (Berger and Luckmann, 1966:38). Berger and Luckmann use the term "symbol" to refer to language which "spans spheres of reality" (1966:38).

Language also exists in "classification schemes" or "semantic fields." These fields have different levels of distribution through the society. One field consists of the basic knowledge shared by others in the community. Others are the "property" of specialized groups within the community, for example the semantic field of sociologists or that of professional clergy. Access to the specialized 
language fields is typically carefully controlled.

Within society there are established means of

transmitting the basic stock of what "everyone" knows, as

well as provision for initiation of the chosen into the

more specialized fields. Much of this transmission is done through language.

Language objectivates the shared experiences and makes them available to all within the linguistic community, thus becoming both the basis and the instrument of the collective stock of knowledge. Furthermore, language provides the means for objectifying new experiences, allowing their incorporation into the already existing stock of knowledge, and it is the most important means by which the objectivated and objectified sedimentations are transmitted in the tradition of the collectivity in question (Berger and Luckmann, 1966:64).

The influence of language on the way such new experiences are incorporated will be discussed later.

\section{RELIGION AND EXPERIENCE}

Andrew Greeley, in The Mary Myth (1977), quotes Clifford Geertz' typology of religion as

1. a system of symbols which acts to

2. establish powerful, pervasive, and long-lasting moods and motivations in men [sic] by

3. formulating conceptions of a general order of existence and

4. clothing these conceptions with such an aura of factuality that

5. the moods and motivations seem uniquely realistic. (Geertz, $1968: 642$ ).

Geertz felt that these symbols function "both as models of divine existence and models for human behavior" 
(Christ and Plaskow, italics in original, 1979:2). Thus if the pastor is male and seen as being a symbol of the deity, the deity is seen as male. It would then be logical to assume that the same process would take place with a female pastor. Conflict can occur with the disjunction between the accepted historical meaning of what is being symbolized and the physical manifestation of that symbol in the person of the [female] pastor.

Feminist theologian Rosemary Radford Ruether agrees with the position that religious symbols come from experience and that they must continuously be renewed by experience.

"Experience" includes experience of the divine, experience of oneself, and experience of the community and the world, in an interacting dialectic. Received symbols, formulas, and laws are either authenticated or not through their ability to illuminate and interpret experience (Ruether, $1983: 12$ ).

The problem for feminists comes when the authority systems attempt to reverse the process by making the symbols define both what can be experienced and how the experience is to be interpreted.

Greeley states that "religion takes its origin from experience, and religious communication is primarily designed to lead to the replication of experience" (1977:24). In other words, if experience of the sacred has been expressed in male-oriented symbols, the symbols used 
for the replication of that experience will be maleoriented.

A problem arises when a person has what Greeley calls limit-experience. In a limit-experience, the old perceptions are shattered and new ones are structured. He believes that the person having the experience will express it in terms of the old symbols because "in one very real sense, the symbol is the experience" (Greeley, 1977:34, italics in the original). The purpose of religious communication is to reproduce that experience by sharing it with others. In order to do that, it is necessary to use the existing symbols.

Religion functions as a way for humans to give meaning to life. It is "a symbolic interpretation of ultimate reality" (Greeley, 1977:24). Part of that reality is the undisputable fact that humans come in both male and female forms. To quote Greeley again, there is "a great tradition of female deities, all of whom reflect the human conviction that God has feminine as well as masculine characteristics, a conviction arising spontaneously and inevitably from the profound, disturbing, and shattering experience of sex differentiation" (Greeley, 1977:13).

A close look at his introduction to the study of the Mary myth reveals that Greeley himself makes the claim that "the structure and function of the Mary myth are 
designed to reveal the femininity of God" (Greeley, 1977:20). Later he states that "the notion of an androgynous deity is certainly not incompatible with the religious perspective with which we were raised" (Greeley, 1977:52). However, the symbolism of Mary is not given equal importance to the symbolism of God as father, particularly in the non-Roman Catholic denominations. Therefore, Mary symbolism does not seem to have the same availability for expressing experience of feminine aspects of the divine in terms of existing symbols.

\section{SYMBOLIC BOUNDARIES}

In his 1988 book, The Restructuring of American Religion, Robert Wuthnow looked at the post-World war II changes in the structure of religion in the United states in terms of changes in the "symbolic boundaries." One of these changes was the change in the "categories that are taken for granted in religious discourse" (Wuthnow, 1988:10). The role of women in liturgy is one of these areas of change.

Wuthnow saw gender discrimination as an important factor in the polarization of religious liberals and conservatives. He based his view on three arguments: church attendance patterns, the influence of feminism, and the presence of ideological barriers between liberals and 
conservatives.

Attendance patterns: Participants in organized worship services are traditionally predominately women. This has not changed, even as women's roles in the rest of society have changed. There is also an age-related pattern of interest in organized worship services. It is relatively high during adolescence, drops during early adult life and then rises slowly through the remainder of life (Glock, Ringer, and Babbie, 1966:53; Greeley, 1989:55). There is evidence, though, that for women with children, the decision about participation in organized religion is made during the children's adolescence and before the mother's 50th birthday.

Glock and his co-workers also found that commitment to church membership is strongest among those whom the general society holds in lower esteem - the unmarried, widowed, divorced, childless. (It should be noted that their research took place before the work force changes of the 1970s.)

Women who are denied serious consideration for the responsible positions in secular society find they can be very important to the life of the church. In sum, the church offers a refuge for those who are denied access to valued achievements and rewards in everyday American life (Glock, et al., 1966:107)

Feminism: In the 1970s, feminism altered some women's participation patterns. In his 1963 work on church mergers, Peter L. Berger found that potential church 
members in the "main-line" Protestant denominations were recruited from the suburbs and from among sophisticated consumers. "It has become a truism to say that main-line Protestant denominations... have an increasingly homogeneous middle-class population" (Berger, 1963:82). Shortly after he wrote this, however, the women in that population - "young and better educated women, those with professional careers, and women who already had more secular orientations toward life" (Wuthnow, 1988:227) began to answer the call of feminism. They wanted change more quickly than their denominations were able to change.

This soon created disparity between the religious involvement of feminists and nonfeminists. In most mainstream denominations, nonfeminists were considerably more active in churches than were the feminists. Wuthnow did find three notable exceptions.

Among Presbyterians and Jews, feminists were no less likely to attend church [sic] regularly.... And among Episcopalians, feminists were 11 percentage points more likely to attend regularly than were nonfeminists (Wuthnow, 1988:229 citing General Social Survey Cumulative File, 1972-1984).

In the other denominations, the most active women were likely to be nonfeminists.

By the 1990s, there was a large cohort of highly educated women who have had greater access to the "valued achievements and rewards" of American life, and who were at the life stage Glock and co-workers found to be crucial 
in determining church membership.

Ideological barriers between religious liberals and conservatives: The movement to make the changes necessary to allow for the ordination of women found religious liberals and conservatives on the opposite sides of seemingly unsolvable ideological divisions. One of these barriers concerns the function of the church. To comfort and to Challenge, the title of a 1966 work by Charles Glock, Benjamin Ringer, and Earl Babbie, refers to two different functions. The church can, on the one hand, serve as an institution which comforts people by ministering to their needs (the "priestly" function), in which it functions to maintain societal values and to support social stability. The alternative, challenging function is often called the prophetic function, calling for social change. Typically, the two do not coexist comfortably.

On the one hand, religion supplies the "values, beliefs and moral principles which a people share [to] represent an ideal picture of society as they feel it ought to be" (Glock, Ringer, and Babbie, 1966:2). On the other, the church is also the place one goes for "spiritual first aid," the place where "the values of social harmony and tranquility...have the effect of preventing movements toward social justice" (Glock, 
Ringer, and Babbie, 1966:205). As Edward Lehman put it, "Eschewing dissension and schism is assumed to be beneficial for the maintenance of group loyalty and continued participation" (Lehman, 1985:112). The problem is that sometimes these shared religious values of the group are the cause of the need for first aid.

Another ideological barrier between liberals and conservatives concerns the nature of the church. Alan Black (1988) found that there are two basic concepts. One uses the idea of the church as an organism, "an integrated whole made up of functionally interdependent parts." This organism is greater than the sum of its parts and has needs of its own. It "grows" and changes over time. A Biblical expression for this is found in one of the epistles of St. Paul, "For just as the body is one and has many members...so it is with Christ" ( 1 Cor. 12:12). Contrasting with the idea of the church as organism is the idea of covenant. This concept is also found in the writings of St. Paul (2 Cor. 3:4). The covenant image portrays the church as a contractual organization. A basic assumption is that the individuals who participate do so because of their own needs rather than because of the needs of the organization. Indeed, the organization is conceived of as a tool to meet these needs. It should be noted that elements of both models are usually present in 
any given denomination and conflict can arise between their respective proponents.

The symbolic nature of the ministry is another ideological barrier between conservatives and liberals. It matters whether clergy are seen as the representative of Jesus the man, or of the church, the so-called Bride of Christ. If clergy are believed to be representing Jesus, a case can be made for restricting the priesthood/ministry to men. On the other hand, if they are representing the church, women would be equally appropriate.

Transcendence vs. immanence of God is the final liberal/conservative ideological barrier to be considered. The idea of the divine power (God or gods) as transcendent sees the divine as separate from, and external to, human life. Transcendence is usually seen as a male attribute. The Hebrew Yahweh is an example. Immanent divinity, on the other hand, dwells within. It inspires (in-spirits) all of creation. The various forms of the Earth Mother and the Christian Holy Spirit fall within this definition.

FUNCTION AND DYSFUNCTION

Thomas O'Dea and Janet O'Dea-Aviad described two basic functions of religion.

One is a larger view of a beyond, in the context of which deprivation and frustration can be experienced as meaningful. The other is the ritual means for facilitating a relationship to the beyond which gives 
enough security and assurance to human beings to sustain their morale (O'Dea and O'Dea-Aviad, $1983: 14$ ).

In doing this it can either reinforce social stability (like the priestly function mentioned above) or it may "prove itself an unsettling or even subversive influence in any particular society" (the prophetic function) (O'Dea and O'Dea-Aviad, 1983:16).

Either of these functions can be extended to the point of dysfunction. One of the priestly dysfunctions is that of inhibiting protest on the part of those who are on the margins of the society. It does this by providing consolation and emotional support instead of addressing legitimate grievances.

Secondly, finite ideas can become identified as sacred, eternal ones. Similar to this is the tendency for behavioral norms and values appropriate to a specific time and place to be maintained long after the circumstances in which they arose have changed. The so-called Biblical family is an example. In it the New Testament example of Mary, Joseph, and Jesus is seen to portray the "normal" relationship between a married man, his wife, and their biological child. Proponents of the idea overlook the fact that Joseph was not Jesus' biological father.

In the prophetic function, criticism may be so extreme and intolerant that it moves beyond the point at 
which compromise is possible. The Pro-Choice and the ProLife sides of the abortion issue approach this kind of dysfunction.

Exacerbating this dysfunction is another: people may identify with their religion to the point that they are unwilling to negotiate with an opponent, even when the situation which originally created the conflict has changed. The religious wars at various times in history (including the present) are examples.

Finally, O'Dea and O'Dea-Aviad (1966) believe religion can cause immaturity to be institutionalized so that members become dependent upon their leaders. Many feminists criticize Christianity for this very thing.

FEMINISM, RELIGION AND THE HISTORICAL MOMENT

Francesco Alberoni in his 1984 book, Movement and Institution, discussed the idea that institutions undergo change in response to a specific historical moment and that there is an identifiable pattern by which this change occurs. While the institution is in the process of change, the customary means of social solidarity are no longer adequate. While new solidarity in response to the nature of the specific historical moment is in the process of being created, the institution is said to be in a nascent state. 
In the typical pattern, one part of the original system creates a proposal for the entire system's reconstruction. Alberoni calls this an "alternative solidarity" which develops when individuals, who were not previously in relationship with one another, come together to form new nuclei of power within the system. These nuclei then gather together in "movements" whose success or failure depends on their ability to meet the specific challenge facing the institution. A key aspect of this phenomenon is what Alberoni refers to as the "fundamental experience." By this he means the way in which the group explores the available means for attaining solidarity in the historical moment.

The fundamental experience of the nascent state arises when a threshold of structural preconditions has been met. Reaching this threshold will affect people's lives, especially those who are "frustrated by a situation in which they are deeply and sincerely rooted" (Alberoni, 1984:47). Their frustration arises because they have not received what they expected. They will, however, generally continue their loyalty to the original organization or group until they find an alternative which seems to them to be unavoidable.

It is typical for those participating in the fundamental experience to form a movement. Those in the 
movement develop a way of life that is quite different from that of the existing institution. In the process the movement must begin to institutionalize itself and in so doing, it comes into conflict with everyday customs and institutions. This conflict eventually is resolved and results in an altered form of the everyday customs and institutions.

The early stages of this process can be seen in feminist/ church relationships by looking at the development of the much criticized RE-imagining Conference described above. The original purpose of the conference had been to spend one weekend exploring new language and images for God with no thought of continuing to meet after the event. After the resulting controversy, the steering committee of the conference incorporated and began publishing a newsletter. The success of this movement is yet to be determined.

In 1934, H. Paul Douglass wrote a book about church merger in which he quoted from the Proceedings of the World Conference held in Lausanne in 1927. He noted in the book that "the rank and file of the people of the churches to be united have little consciousness of the things which the conference discussed" (Douglass, 1934:xxvii). The same thing could undoubtedly be said about inclusive language.

It is one thing for seminarians to argue points, or 
for national level bureaucrats to make decisions, and quite another for the issue to come to the attention, much less into the practice, of the average person in the pew on sunday morning. Continuing his discussion of mergers, Douglass later wrote,

Still more doubtful is it whether religious reintegration ... can take place without the institutionalization of newly recognized values in a churçh (Douglass, 1934:217).

Feminist theology in general, and inclusive language for God specifically, represent newly recognized values held by at least some members of the religious community. The remainder of this paper examines evidence of institutionalization of inclusive language for God in the liturgical (worship) setting. 
CHAPTER THREE

METHODOLOGY

\section{INTRODUCTION}

Since the end of World War II, there has been a change in the roles of women in mainstream Protestant denominations in the United States. More denominations now ordain women, and the percentage of clergy who are women has increased.

As the presence of ordained women became more noticeable, inclusive language for God became a newly recognized value, held primarily by Christian feminists. Other portions of the mainstream Protestant community cling to the traditional symbol system and its use of masculine language and imagery for God. There is conflict between the two groups which appears to be at least somewhat threatening to the stability of the denominations involved.

The remainder of this study examined the use of inclusive language for God in the liturgical setting and the possibility that its use in a given congregation is related to that congregation's experience with women clergy. This was accomplished by examining various congregations in the Portland area which are affiliated 
with specific denominations. Areas to be examined are experience with women clergy, use of inclusive language for God, congregation demographics, and clergy characteristics.

\section{POPULATION}

I originally chose six mainstream, Protestant, Christian denominations, all of which have been ordaining women for a period of 15 years or longer: The Unitarian/Universalist Fellowship (U/U), The United Church of Christ (UCC), the United Methodist Church (UMC), the Presbyterian Church USA (PCUSA), the Episcopal Church (ECUSA), and the Evangelical Lutheran Church in America (ELCA). Each of these has a national organization.

Because individual congregations vary in the degree to which they accept new ideas and procedures, I also looked at six congregations in the Portland area for each of the six denominations. In order to simplify the interview process, I decided to interview one pastors from each of the congregations, the pastor being the person in the congregation most likely to have access to the information I was seeking. A questionnaire (described in a following section) was used to make the content of the interviews more uniform.

After telephoning six of the seven $U / U$ congregations 
in the Portland telephone book, I discovered that only three had pastors. The others were fellowships. Because I talked with pastors in all the other denominations, I decided to drop the $U / U$ congregations from my numerical analysis.

\section{SAMPLE SELECTION PROCEDURE}

Rather than try to predict which congregations did and which did not have experience with women pastors, I went through the Yellow Pages of the Portland telephone book and called the first six alphabetical listings in each denomination. At the time I called to request an appointment, I gave a brief description of my project and an estimate of the time involved to complete the questionnaire. I also explained that it was voluntary.

If I was unable to make contact (line busy or no answer) after four calls, I went to the next listing. When my call was answered by an answering machine, I left a message. If there was no response by the following week, I again went to the next listing. Because language was one of my variables, I eliminated any congregation whose name suggested they used a language other than English.

Although it was sometimes difficult to convince the person answering the phone that I wanted to talk to the pastor regardless of the pastor's gender, the vast 
majority were most willing to talk with me. The fact that nearly all of them had written a master's thesis may have helped. Only one pastor refused; one did not show up for our appointment; only one congregation's secretary insisted I needed to talk with the lay director of education (a woman) rather than the pastor (a man). What I found interesting is that all three of these belong to the same denomination.

The time necessary to address the items in the questionnaire ranged from one pastor who took 15 minutes to another who took an hour and a half. Many of the pastors seemed to see my visit as a "safe place" to talk about their experience and their frustrations. All but four interviews took place in the pastors' offices. Two pastors met me at restaurants; one met me in the church office and then we walked to a nearby coffee shop; and one talked with me on the construction site of the congregation's new facility.

At the interview, I introduced myself and reminded the interviewee of the purpose of my project. I then proceeded to ask each of the questions on the questionnaire. I asked the questions in person rather than leaving the form for them to fill out and return to me in order to increase my return rate. As it turned out, even the questions about demographic information generated much 
discussion which provided qualitative information.

\section{THE QUESTIONNAIRE}

The development of the questionnaire was based on the qualitative research design work of Catherine Marshall and Gretchen B. Rossman (1989). Their work lists several categories of qualitative research, one of which they call "explanatory" (1989, p. 78). This seemed to be the most appropriate model for what I was undertaking so I designed my questions in line with their suggestions.

The questionnaire (see Appendix A) had both survey questions and questions which were intended to guide a more in-depth interview. Questions which required specific answers, like "how big is the congregation," were designed to provide generalizable quantitative data by which the congregations could be easily compared. Other questions were open-ended to provide an opportunity for the unique experience of each individual congregation to be analyzed.

The two types of questions required two types of analysis. For the questions asking specific information, numerical analysis was used. The answers to the open ended questions were analyzed by content analysis. The results are given in the next chapter.

In addition to the two types of questions, the questionnaire contained three sections. The first asked 
for general demographic information. The purpose of this section was to look for indicators of change in the congregation, independent of women in ministry. This includes such things as birth cohort of membership, socioeconomic status, education, and ethnicity.

The second section looked for clergy characteristics such as the pastor's tenure, seminary, cohort of ministerial training, presence/absence of peers in congregation, and denomination characteristics. Two questions were designed to identify whether or not the congregation had any experience with women clergy as members of the paid staff. This section was intended to examine the possibility that clergy characteristics might be related to the use of inclusive language in liturgy in that congregation.

The final section addresses the issue of inclusive language in liturgy and sought to determine if it was being used. In those cases where it was used, there were questions about how it was used and who had made the decision to do use it. Even though my interest was in the language used for God in prayer, preliminary research indicated that it would be necessary to ask specific questions about the various ways in which worship communities talk about and to God. Thus, there are questions about the language used in hymnody, sermons, and 
Christian education material, as well as in prayer.

There were also questions about the frequency of use and about the settings in which the language is used, whether or not there were plans to change this, and how, as well as why the decision to begin using it had been made. 
CHAPTER FOUR

DATA

CONGREGATIONAL QUESTIONNAIRE

My original intent had been to interview the pastors of six congregations in each of my chosen denominations three which had experience with women clergy and three which did not. In actuality, more congregations have had experience with women clergy than I had anticipated. I ended up with three categories for congregational experience with a woman pastor -those which currently had women pastors, those which did not currently have women pastors but had had them in the past, and those which had never had them.

Because the sample size is quite small, the results will be analyzed on the basis of category (experience with women clergy) rather than on denomination. There are eleven (11) congregations in the category of Woman Pastor Now on Staff. Another eleven (11) have had a woman pastor in the past. The remaining eight (8) have had no experience with a woman pastor on staff.

The use of inclusive language for God also fell into 
three categories - those in which it was the norm, those which use it on occasion, and those which never use it. Again, I will not discuss congregations by denomination. When sorted by language usage, there are ten (10) congregations (one-third of those examined) which use inclusive language for God on a regular basis. There are 13 congregations which use it some of the time and the remaining seven (7) do not use inclusive language for God in their communal prayer, which is the focus of this analysis.

\section{DEMOGRAPHIC INFORMATION}

The first section of the questionnaire covered demographic information about the congregations. The pastors' responses to the questions are given below. There are two tables for each question. The first table for each question separates the congregations into language use categories. The second table for each places the congregations into categories of experience with women clergy. The majority of the answers represent the pastor's perception, although one pastor referred to a recently completed congregational profile when responding to these questions. 
Table 1. Size of Congregation by Language Use

\begin{tabular}{llll}
\multicolumn{2}{c}{$\begin{array}{c}\text { Language Use } \\
\text { Use Inclusive } \\
\text { Language }\end{array}$} & $\begin{array}{c}\text { Some Use of } \\
\text { Inclusive } \\
\text { Language }\end{array}$ & $\begin{array}{c}\text { Never Use } \\
\text { Inclusive } \\
\text { Language }\end{array}$ \\
Size $\begin{array}{l}\text { Fewer than } \\
100 \text { members }\end{array}$ & 3 & 1 & \\
$\begin{array}{l}100-249 \text { members } \\
250-500 \text { members }\end{array}$ & 3 & 6 & 4 \\
more than 500 & 1 & 3 & 2 \\
members & 3 & 3 & 1
\end{tabular}

The pastors gave the size of their congregations according to the method used by their denomination. Some denominations include children and inactive members;

others limit their membership count to currentiy active adults, making it somewhat difficult to compare congregation size. However, even allowing for differences in how size is determined, there does not seem to be any clear size related difference between the congregations when separated either by language usage categories (Table 1) or by experience with women clergy (Table 2).

It may be observed that there were the same number of largest and smallest congregations in the category which always uses inclusive language. None of the congregations which never use inclusive language had fewer than 100 members. In all language categories, the majority of the congregations had fewer than 250 members. Thus, congregation size does not appear to determine language 
type.

Table 2. Size of Congregation by Experience with Woman Clergy

Experience with Woman Clergy

Woman Clergy Woman Clergy No Experience On Staff Now on Staff in with Woman the Past Clergy on

Fewer than

100 members

Size 100-249 members 4

250-500 members 2

$2 \quad 1$

3

more than 500

members

3

Staff

$\begin{array}{ll}1 & 1 \\ 3 & 6 \\ 4 & 0 \\ 3 & 1\end{array}$

As shown in Table 1, three of the four congregations with fewer than 100 members use inclusive language for God on a regular basis. The fourth small congregation uses it some of the time. However, these four congregations were less similar when placed in categories of experience with women clergy. Two of the smallest congregations currently had a woman pastor, one had had a woman pastor in the past, and the third had no experience with a woman pastor. of the congregations which had a woman pastor on staff in the past, more had at least 250 members than had fewer than 250. All but one of the congregations having no experience with women clergy had fewer than 250 members.

The relationship between congregation size and experience with women clergy may be in flux. When women were first ordained in significant numbers they were most 
likely to find positions as assistants in congregations with two or more pastors. However, several of the pastors (both male and female) told me that many small congregations find the idea of a married woman pastor quite desirable if her husband has health insurance because that significantly reduces the congregation's payroll expense.

My original question about age characteristics asked the pastors to indicate whether their congregations were predominately comprised of Young Families, Senior Citizens, Single Adults, or Mixed (all of the above). None of the pastors indicated that their congregation was predominately comprised of single adults, so I eliminated this category. The category "Other" was added after two pastors said their congregations contained roughly equal proportions of Senior Citizens and Young Families without the intervening generation of people in their $40 \mathrm{~s}$ and $50 \mathrm{~s}$.

Table 3. Congregation Age Characteristics by Language Use

\section{Language Use}

Use Inclusive Language

Young Families

Age Senior Citizens

Mixed

Other*

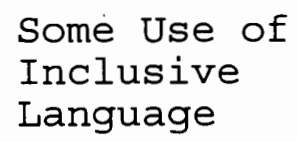

Inclusive

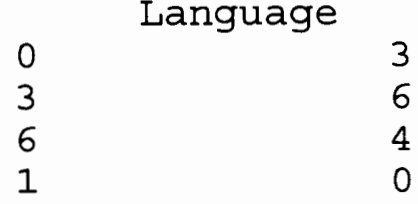

Never Use Inclusive Language

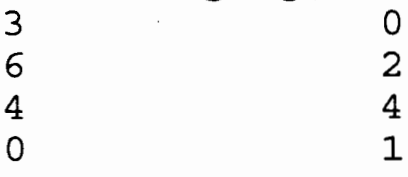

*young families \& seniors without intervening generation 
The majority of the congregations in which senior Citizens are the dominant group use Inclusive Language for God at least some of the time. It may be noted that the three congregations in which Young Families are dominant is in the "Some Use" language category. In contrast, the two congregations in the "Other" category (the one with young families and seniors with out the intervening generation) either use such language all the time or do not use it at all. The reason for this is not known.

Table 4. Congregation Age Characteristics by Experience with Woman Clergy

Experience with Woman Clergy

Woman Clergy Woman Clergy No Experience On Staff Now on Staff in with Woman

Past Clergy

Young Families

Age Senior Citizens mixed

Other*

$\begin{array}{lll}0 & 3 & 0 \\ 3 & 4 & 4 \\ 6 & 4 & 4 \\ 2 & 0 & 0\end{array}$

*young families \& seniors without intervening generation

As mentioned above, the congregations in which young families are predominant are all congregations which have had women pastors in the past. These three congregations are also in the "Some Use of Inclusive Language" category. The two congregations in the category with Young Families and Senior Citizens but not people in their 40 s and 50 s are both congregations with a "Woman pastor Now on Staff." This suggests that language usage and clergy gender may be influenced by the age characteristics of the congregation. 
The ethnicity of twenty-four of the congregations was Euro-American. Five congregations were of mixed ethnicity. The remaining congregation was primarily African-American. To protect confidentiality it is not shown on either the language use or the experience with woman clergy table.

Table 5. Ethnicity of Congregation by Language Use Language Use

\begin{tabular}{cccrc}
\multicolumn{2}{c}{$\begin{array}{c}\text { Use Inclusive } \\
\text { Language }\end{array}$} & $\begin{array}{l}\text { Some Use of } \\
\text { Inclusive } \\
\text { Language }\end{array}$ & $\begin{array}{c}\text { Never Use } \\
\text { Inclusive } \\
\text { Language }\end{array}$ \\
Ethnicity Euro-American & 7 & & 11 & \\
Mixed & 2 & 2 &
\end{tabular}

The percentage of mixed congregations is somewhat higher for those congregations which use inclusive language for God than for those which make some use of it and those which never use it $(22 \%$ Use, $15 \%$ Some Use, $14 \%$ Never Use) but the sample is too small for the finding to be significant.

Table 6. Ethnicity of Congregation by Experience with Woman Clergy

Experience with Woman Clergy

Woman Clergy Woman Clergy No Experience On Staff Now on Staff in with Woman

Ethnicity Euro-American 8 the Past Clergy Mixed 10 6

The only apparent difference in these groupings by ethnicity is that none of the mixed congregations had had 
a woman pastor in the past. The reason for this is unclear.

Table 7. Dominant Education Level of Congregation by Language Use

Language Use

\begin{tabular}{|c|c|c|c|c|}
\hline & & $\begin{array}{l}\text { Use Inclusive } \\
\text { Language }\end{array}$ & $\begin{array}{l}\text { Some Use o } \\
\text { Inclusive } \\
\text { Language }\end{array}$ & $\begin{array}{l}\text { Never Use } \\
\text { Inclusive } \\
\text { Language }\end{array}$ \\
\hline & Less & than college & $2-5-5$ & \\
\hline ducation & Some & College & 5 & \\
\hline Level & $\begin{array}{l}\text { Even } \\
\text { of co } \\
\text { colle }\end{array}$ & $\begin{array}{l}\text { distribution } \\
\text { ollege \& non- } \\
\text { eqe }\end{array}$ & 3 & \\
\hline
\end{tabular}

Each language category contains a majority of congregations in which the dominant education level includes at least some exposure to college. However, the percentages of college exposure within categories are much higher for those congregations using inclusive language for God at least some of the time than for the "Never Use Inclusive Language" category $(80 \%$ Use, $84 \%$ Sometimes, $67 \%$ Never) .

On the other hand, as seen in Table 8 , education does not seem to be related to the congregation's experience with a woman pastor on staff. It should be pointed out that age is a factor in college attendance. College attendance levels are much higher for people born after 1940 than for those born prior to that date. As a result, congregations in which senior adults are predominant can be expected to have lower rankings with regard to college 
attendance.

During the interviews, it appeared to me that pastors in denominations which include children in their membership counts excluded the children when discussing education level. That is to say, in their responses to my question about the dominant education level of their congregation, the pastors gave the dominant education level of the adults. It is likely that few of the children in young families had been to college.

Table 8. Dominant Education Level of Congregation by Experience with Woman Clergy

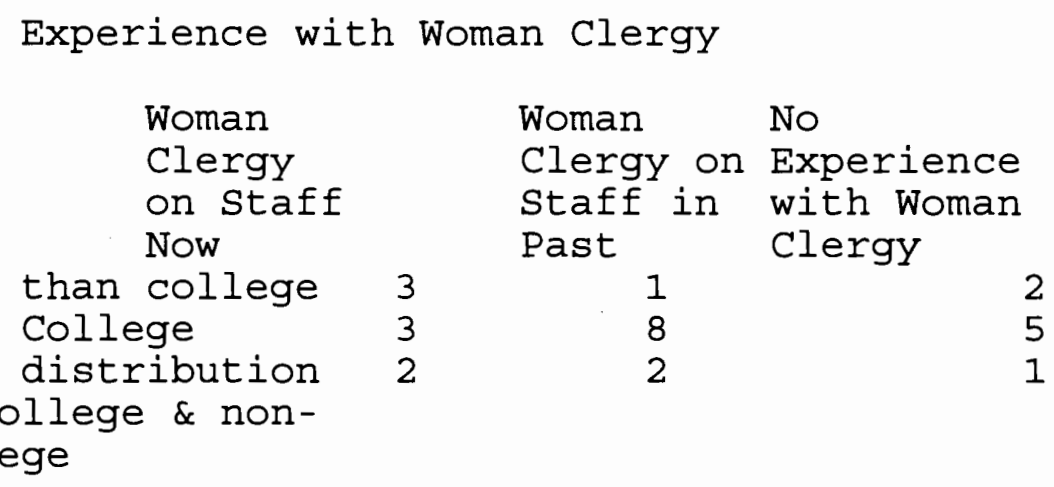

I examined perceived income characteristics in two ways. The first question identified four categories of income: two-paycheck households, households with fixed income (such as social security, pension, welfare), households in which one member was the breadwinner, and a category called "all" to be used by any congregation in which all the above were present in roughly equal proportions. 
A fifth category, "mixed" was added after several pastors indicated that their congregation contained nearly equal numbers of two-paycheck households and households with fixed income. There are more congregations in the mixed income category than there were in the mixed age category, thus the two cannot be equated.

Table 9. Congregation Income Type by Language Use Language Use

Use Inclusive Language

Two-paycheck households

Income Fixed income

Type households 2 No dominant type 4 Mixed* 2

Some Use of
Inclusive
Language
3 1
Language

\section{8} 2

2

1
Never Use Inclusive Language

* Households perceived to have nearly equal numbers of two-paycheck households and households with fixed income

None of the pastors reported that their congregation was composed of primarily one-paycheck households so this category was not included in Tables 9 and 10. Four congregations were perceived to be primarily fixed income households. All of these used inclusive language for God at least some of the time.

It may be observed that the proportion of twopaycheck households was much greater in the "Some Use of Inclusive Language" category than in the other categories. While this could be an indication that congregants are influenced by "market place" values like Equal Opportunity 
Employment, the four "fixed-income" congregations all make at least some use of inclusive language and would appear to be less influences by "market place" values. Determining this is beyond the scope of the current research but could merit investigation in the future.

Table 10. Congregation Income Type by Experience with woman Clergy

Experience with Woman Clergy

Woman Clergy Woman Clergy No Experience On Staff Now on Staff in with Woman

Two-paycheck $\begin{array}{llll}\text { households } & 6 & 4 & 4\end{array}$

Income Fixed income

Type households $\quad 0 \quad 2 \quad 2$

No dominant type $3 \quad 5 \quad 1$

$\begin{array}{llll}\text { Mixed* } & 1 & 2 & 1\end{array}$

* Households perceived to have nearly equal numbers of two-paycheck households and households with fixed income

The congregations with past experience with a woman clergy have more variety in terms of income type than do the other categories. It may be observed that none of the congregations in which fixed income households predominate are in the category of woman clergy currently on staff. However, there does not appear to be enough difference in the income type of the three categories of experience with woman clergy to represent any clear relationship.

The second income question asked for the pastors' perceptions about the dominant source of income for their 
congregations. The categories included: wage or salary, self-employed, fixed income of any type, and one for congregations in which no one type was dominant.

Wage or Salary is the dominant source of income in the majority of congregations in the categories which use inclusive language for God at least some of the time. In the category of "No Use of Inclusive Language, " Wage or Salary is the dominant source of income for less than half the congregations. Thus, the dominant type of income source may influence the congregation's use of inclusive language for God, possibly through work experiences congregants have.

Table 11. Congregation Income Source by Language Use Language Use

Use Inclusive Some Use of Never Use Language Inclusive Inclusive Language Language

Income Wage or Salary 7 Self-employed 0 Source Fixed income 2 No dominant type 1 7 0 2 4

There is less difference between categories of income type when the congregations are grouped by experience with woman clergy. In this case, at least half of each usage category is made up of congregations in which wage or salary is the dominant income type. 
Table 12. Congregation Income Source by Experience with Woman Clergy

$$
\text { Experience with Woman Clergy }
$$

Woman Clergy Woman Clergy No

On Staff Now on Staff in Experience with Woman Clergy

$\begin{array}{lll} & \text { Wage or Salary } & 6 \\ \text { Income } & \text { Self-employed } & 0 \\ \text { Source } & \text { Fixed income } & 1 \\ & \text { No dominant type } & 4\end{array}$

$\begin{array}{ll}7 & 4 \\ 0 & 0 \\ 2 & 2 \\ 1 & 2\end{array}$

The question about typical occupation also failed to yield any clear pattern. The scores given in the various categories in Tables 13 and 14 differ from those above because the pastors were unwilling to characterize the entire congregation as being in any one occupation category. Instead, they indicated all categories represented by members of their congregation. Retired persons were included in the category from which they retired.

Table 13. Occupation of Congregation Members by Language Use

\section{Language Use}

$\begin{array}{lll}\text { Use Inclusive } & \text { Some Use of } & \text { Never Use } \\ \text { Language } & \text { Inclusive } & \text { Inclusive } \\ \text { Language } & \text { Language }\end{array}$

$\begin{array}{cll} & \text { Labor } & 3 \\ \text { Typical } & \text { Service } & 4 \\ \text { Occupation } & \text { Clerical } & 6 \\ & \text { Business } & 6 \\ & \text { Professional* } & 6\end{array}$

*Includes teachers Note: For this question, the pastors indicated ALL categories represented in their congregations 
Professional people, including teachers, appear to be less represented in congregations in the "Use Inclusive Language" category. In the other two language categories, professional people out-number any of the other given occupation types. Business and Professional people together were more dominant in the language categories "Some Use of Inclusive Language" and "No Use of Inclusive Language" than they were in the "Use" category.

Clerical workers had the lowest representation in the "No Use" category and greatest in the "(Always) Use Inclusive Language" category. There may be a relationship between sensitivity to language and the large numbers of clerical workers who are women. Such a determination is beyond the scope of this study.

Table 14. Occupation of Congregation Members by Experience with Woman Clergy

Experience With Woman Clergy

Woman Clergy Woman Clergy No Experience on staff Now staff in Past with Woman

$\begin{array}{lrrr}\quad \text { Labor } & 4 & 2 & 4 \\ \text { Typical Service } & 3 & 4 & 3 \\ \text { Occupation Clerical } & 4 & 6 & 6 \\ \quad \text { Business } & 6 & 7 & 5 \\ \text { Professional* } & 10 & 10 & \text { Clergy } \\ \text { *Includes teachers } & & \\ \text { Note: For this question, the pastors indicated ALL } \\ \text { categories represented in their congregations }\end{array}$

When the congregations are grouped by experience with 
woman clergy, the largest occupational category was "Professional" for congregations in the categories "Woman Clergy in the Past" and "Woman Clergy on Staff Now," while the large occupational category for congregations in the "No Experience with Woman Clergy" category was "Business." This again may be related to contact with social issues like Affirmative Action which are beyond the scope of this study.

The final question in the section of my questionnaire concerning congregation characteristics looked for evidence of social change within the congregation during the past five or ten years. The purpose of this question was to examine the possibility that experience with change in size, dominant age, or social diversity (such as ethnicity or sexual orientation) may be influencing the congregation's use of inclusive language for God or its experience with a woman pastor.

Language use seems unrelated to a congregation's experience with change. Only one pastor indicated that the congregation had increased in size and that congregation was in the category which used inclusive language some of the time. The "Some Use" category also contained the only congregation for which the pastor indicated the average age was increasing. 
Table 15. Congregation Change in the last 5 - 10 years by Language Use

Language Use

Use

Use Inclusive Some Use of Never

Inclusive

Language Inclusive

$\begin{array}{ccccc} & & \text { Language } & \text { Language } \\ \text { Congregation Increase in size } & 0 & 1 & 0 \\ \text { Change Decrease in size } & 1 & 1 & 2 \\ \text { Average Age Older } & 0 & 1 & 0 \\ \text { Average Age Younger } & 3 & 5 & 2 \\ \text { More Social } & & & 1 \\ \text { Diversity } & 1 & 0 & 2 \\ \text { No change } & 5 & 5 & \end{array}$

All three usage categories had congregations in which the average age of congregants was decreasing. Of the two congregations in which the pastor reported an increase in social diversity, one was in the "Never Use" category and the other in the "Use" category.

Table 16. Congregation Change in the last 5 - 10 years by Experience with Woman Clergy

Experience with Woman Clergy

Staff Now

Woman Clergy Woman Clergy No On

Woman on staff Experience in Past with

$\begin{array}{llllr} & & & \text { Clergy } \\ \text { Congregation } & \text { Increase in size } & 0 & 0 & 1 \\ \text { Change } & \text { Decrease in size } & 3 & 1 & 0 \\ & \text { Average Age Older } & 0 & 0 & 1 \\ \text { Average Age Younger } & 3 & 4 & 3 \\ \text { More Social } & & & 0 \\ \text { diversity } & 1 & 1 & 3\end{array}$

No congregations in the "No Experience" category reported decreasing in size and the only congregation 
which was reported as increasing in size was in this category. The "No Experience" category also contains the only congregation with an average age that was reported to be increasing. The largest number of congregations reported to have decreased in size were those in the "Woman Clergy on Staff Now" category.

For all the experience categories, approximately the same number of pastors reported either that the average age was decreasing or that there had not been a change in the last five to ten years. The two congregations which reported an increase in social diversity have had experience with women clergy, one currently and one in the past.

SUMMARY OF RESPONSES TO DEMOGRAPHIC QUESTIONS

Size of the congregation appeared unrelated to either language usage or to experience with woman clergy. The dominant age group in the congregation may be related to both language usage category and experience with woman clergy. There was insufficient information to determine any relationship between ethnicity and either language usage category or experience with woman clergy.

Congregations which used inclusive language for God at least some of the time were congregations in which people with at least some college experience were seen as 
dominant; two-paycheck households were dominant; and wage/salary was the dominant income type. Business or professional was the dominant occupation in the "Some" or "Never" language usage categories. Clerical workers were noted most strongly in the category "Use Inclusive Language" and absent in the "Never Use Inclusive Language" category.

Occupation also may be related to experience with woman clergy. Professional people appeared more often in the categories having experience with woman clergy and business people more often in the "Never" experience category.

\section{CLERGY CHARACTERISTICS}

Because clergy have responsibility for theological aspects of their congregations, the second section of questions sought to determine if there were characteristics of the clergy which could influence the congregation's use of inclusive language for God.

Clergy characteristics were quite consistent across both language usage and woman-pastor experience categories. Most of the clergy I interviewed were sole pastors. Slightly more than half had other clergy associated with the congregation but not on the payroll. Length of service in the current congregation varied from 
a stay of two weeks to more than twenty years. Twenty-four of the congregations had a male senior or sole pastor, four were led by women, and the other two had a male/female co-pastor team. I did not ask about the marital status of the co-pastor teams.

Table 17. Number of Paid Clergy on Staff by Language Use

\section{Language Use}

$\begin{array}{lll}\text { Use Inclusive } & \text { Some Use of } & \text { Never Use } \\ \text { Language } & \text { Inclusive } & \text { Inclusive } \\ & \text { Language } & \text { Language }\end{array}$

Number One paid pastor $8 \quad 8$

Clergy Two paid pastor $2 \quad 1 \quad 2$

on staff Three or more

0

4

0

The four congregations in Table 17 which have three or more paid pastors all use inclusive language at least some of the time and all are in the category of "Woman on Staff Now." The "Use" and "Never Use" language categories are quite similar to each other. All congregations in the "No Experience with Woman Clergy" category have only one paid pastor. Two of these had pastors with half-time positions. 
Table 18. Number of Paid Clergy on staff by Experience with Woman Clergy

Experience with Woman Clergy

Woman Clergy Woman Clergy No

On staff Now staff in Past Experience with Woman clergy

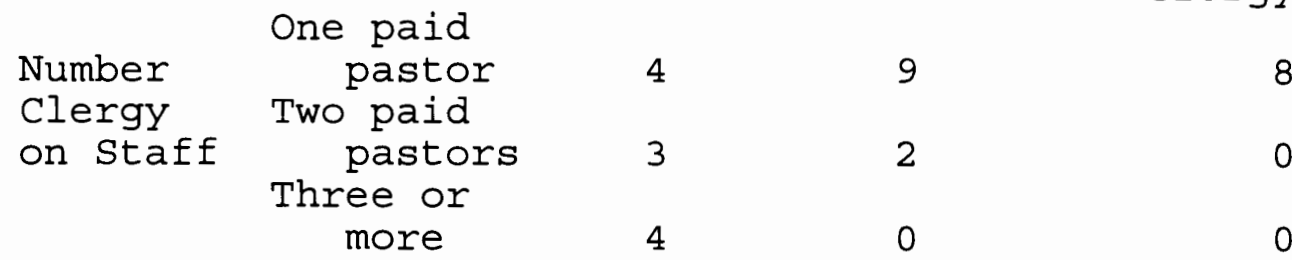

For all categories, the majority of associated clergy were retired pastors, although several congregations had members who were chaplains at hospitals, rest homes, or schools. A few of the associated clergy were active as teachers. In answering this question, one pastor reported that there were 25 members of the congregation who had doctorates in theology who "keep me on my toes." Another pastor indicated that the congregation was located near a retirement home for that denomination's church workers.

Table 19. Presence of Unpaid Clergy Associated with the Congregation by Language Use

\section{Language Use}

Use Inclusive Some Use of Never Use Language Inclusive Language

$\begin{array}{lllll}\text { Number } & \text { None } & 5 & 4 & 4 \\ \text { of Unpaid } & 1-2 & 2 & 3 & 2 \\ \text { Associates } & 3-5 & 2 & 4 & 1 \\ & \text { More than } 5 & 1 & 2 & 0\end{array}$

It appears that the presence of five or more unpaid 
clergy associated with a congregation encourages the use of at least some inclusive language, possibly because the number of associates provides the pastor with a number of alternate points of view coming from peers.

Table 20. Presence of Unpaid Clergy Associated with the Congregation by Experience with Woman Clergy

Experience with Woman Clergy

Woman Clergy
On Staff Now
Woman Clergy on staff in Past
No

Experience with Woman clergy

$\begin{array}{lllll}\text { Number } & \text { None } & 5 & 5 & 3 \\ \text { of Unpaid } & 1-2 & 2 & 5 & 1 \\ \text { Associates } & 3-5 & 2 & 1 & 4 \\ & \text { More than } 5 & 2 & 1 & 0\end{array}$

As was the case in the "Never Use" language category, the "No Experience with Women Clergy" category had no representation in the grouping of congregations with more than five unpaid associates.

The length of time of the pastor's service in the current congregation varied from an interim pastor who had been there for two weeks at the time of our interview to two pastors, each with more than twenty years in the same location. Choice of pastor and the pastor's length of service is influenced by denomination. For most of the denominations in this study, the congregation chooses its own pastor, usually in cooperation with its regional office. Once chosen, the pastor tends to remain as long as 
the pastor desires. In one denomination, however, the pastor is assigned by the denomination's regional office which also controls the pastor's length of stay.

Table 21. Senior or Sole Pastor's Length of Service in Current Congregation by Language Use

\section{Language Use}

$\begin{array}{lll}\text { Use Inclusive } & \text { Some Use of } & \text { Never Use } \\ \text { Language } & \text { Inclusive } & \begin{array}{l}\text { Inclusive } \\ \text { Language }\end{array} \\ & \text { Language }\end{array}$

Senior/Sole Less than

Pastor's one year

1-5 years $6-10$ years

$$
1
$$

Length of

Service in

Current

11-15 years

16-20 years

Congregation

More than

20 years 1

$\begin{array}{ll}3 & 2 \\ 5 & 3 \\ 3 & 0 \\ 1 & 1 \\ 1 & 0\end{array}$

0

1

There appears to be little relationship between the length of senior or sole pastor's service in the current congregation and the use of inclusive language for God. All language categories contain pastors who had recently arrived at the congregation as well as pastors who had served that congregation for many years. In all language categories the majority of the pastors had served for less than ten years. 
Table 22. Senior or Sole Pastor's Length of Service in Current Congregation by Experience with Woman Clergy

Experience with Woman Clergy

$\begin{array}{lll}\text { Woman Clergy } & \text { Woman Clergy } & \text { No } \\ \text { On Staff Now } & \text { on Staff in } & \text { Experience } \\ & \text { Past } & \text { with Woman } \\ & & \text { Clergy }\end{array}$

Less than

Senior/sole one year

Pastor's

Length of

Service in

Current

Congregation

one year
1-5 years
6-10 years
11-15 years
16-20 years
More than
20 years

$\begin{array}{ll}2 & 1 \\ 2 & 5 \\ 4 & 0 \\ 1 & 1 \\ 0 & 1\end{array}$

2

0

It may be observed that none of the congregations which currently had a woman on staff had a pastor who had served that congregation for more than ten years. Also, both congregations in which the pastor had served for more than twenty years had employed a woman as associate or assistant pastor in the past.

The one-to-five year period was the most common length of stay, with the six-to-ten year period next. This was true both when grouped by language category and by experience with women clergy (12 and 7). Two were interim pastors, one in the "Sometimes" category and one in the "Never." 
Table 23. Sex of Senior or Sole Pastor by Language Use

$$
\text { Language Use }
$$

$\begin{array}{lll}\text { Use Inclusive } & \text { Some Use of } & \text { Never Use } \\ \text { Language } & \text { Inclusive } & \text { Inclusive } \\ & \text { Language } & \text { Language }\end{array}$

Sex of

Male

Female 7

Senior/Sole Male/female

team

2

All three language categories contain both male and female pastors. The only visible difference is that only one of the congregations which use inclusive language for God some of the time had a woman as senior or sole pastor. One of the two congregations with a male/female co-pastor team is in the "Use" category and the other in the "Never use" category. Therefore, sex of the senior or sole pastor appears unrelated to the type of language a congregation uses for God.

Table 24. Sex of Senior or Sole Pastor by Experience with woman Clergy

Experience with Woman Clergy
$\begin{array}{ll}\text { Woman Clergy } & \text { Woman Clergy } \\ \text { On Staff Now } & \text { on Staff in } \\ & \text { Past }\end{array}$

Sex of Male 5 Senior/Sole Female 11 Experience with Woman clergy Pastor $\mathrm{M} / \mathrm{F}$ team 2

Of the 30 congregations, eleven currently had a woman on staff. Of these, four congregations had senior/sole pastors who were female and two had male-female co-pastor 
team. The five remaining congregations had a male senior pastor and one or more female pastors serving as associates or assistants. The other 19 congregations either had never had a woman pastor as part of its paid staff or did not have a woman on its paid staff at the time of my interview.

Because the pastor has the primary responsibility for guiding the spiritual life of the congregation, the next question examined the possibility that the kind of seminary the pastor attended influenced the use of inclusive language for God in communal prayer. There are two basic kinds of seminaries. Some are "stand alone" schools run by a specific denomination while others are part of larger, ecumenical "unions" in which students have the opportunity to take classes in seminaries run by denominations other than their own.

Table 25. Seminary Type of Senior or Sole Pastor by Language Use

\section{Language Use}

$\begin{array}{lll}\text { Use Inclusive } & \text { Some Use of } & \text { Never Use } \\ \text { Language } & \text { Inclusive } & \text { Inclusive } \\ & \text { Language } & \text { Language }\end{array}$

$\begin{array}{lllll}\text { Seminary } & \text { Denomination } & 6 & 6 & 3 \\ \text { Type } & \text { Part of Ecumenical } & & & \\ & \text { Union } & 4 & 7 & 4\end{array}$

There are slight differences between the language categories. In the "Use Inclusive Language" category there were more pastors who attended denomination seminaries 
than there were pastors who attended "union" seminaries. The reverse was true for pastors of congregations in the "Some Use" and "Never Use" categories.

Table 26. Seminary Type of Senior or Sole Pastor by Experience with Woman Clergy

Experience with Woman Clergy

$\begin{array}{lll}\text { Woman } & \text { Woman } & \text { No } \\ \text { Clergy on Clergy } & \text { Experience } \\ \text { Staff Now on staff } & \text { with Woman } \\ & \text { in Past } & \text { Clergy }\end{array}$

Denomination

Seminary Part of Ecumenical

Type
Union
5

6
6

5
4

4

The type of seminary the pastor attended made no difference for the congregations in the category having no experience with a woman clergy. Congregations in the two categories, woman clergy on staff in the past and woman clergy on staff now, were almost evenly distributed between the two seminary types. Thus, the pastor's seminary appears to be unrelated to the congregation's experience with women clergy.

Table 27 contains data about the possibility that the pastor's seminary cohort is related to the congregation's use of inclusive language for God. 
Table 27. Year of Ordination of Senior or Sole Pastor by Language Use

\section{Language Use}

$\begin{array}{lllll} & \begin{array}{l}\text { Use Inclusive } \\ \text { Language }\end{array} & \begin{array}{l}\text { Some Use of } \\ \text { Inclusive } \\ \text { Language }\end{array} & \begin{array}{l}\text { Never Use } \\ \text { Inclusive } \\ \text { Language }\end{array} \\ \text { Year of } & \text { before 1960 } & 1 & 3 & \\ \text { Senior/Sole } & 1961-1965 & 3 & 1 & 1 \\ \text { Pastor's } & 1966-1970 & 1 & 2 & 1 \\ \text { Ordination } & 1971-1975 & 1 & 1 & 1 \\ & 1976-1980 & 2 & 1 & 2 \\ & 1981-1985 & 0 & 3 & 0 \\ & 1986-1990 & 2 & 0 & 0\end{array}$

There are some difference between the three categories with respect to the range of ordination dates for senior or sole pastors. There were no congregations which do not use inclusive language for God whose pastor was ordained prior to 1961 or after 1985. This suggests that the use of language may have some relationship to the pastor's seminary cohort, the nature of which merits further study.

Two senior/sole pastors in congregations which use inclusive language for God at least some of the time were ordained after 1990. Two congregations which always use inclusive language for God have senior/sole pastors ordained between 1985 and 1990, but none were ordained after 1990. It may be noted that none of the pastors in the Never Use language category were ordained prior to 1960 or after 1986 . It should also be noted that those ordained prior to 1970 in any denomination are likely to 
be male. This raises two possibilities that the use of such language is related to some personal characteristic of the pastor - theological maturity or professional security on one hand and theological training during a specific historical period on the other.

There appeared to be little relationship between ordination date of senior or sole pastor and congregation experience with women clergy.

Table 28. Year of Ordination of Senior or Sole Pastor by Experience with Woman Clergy

Year of Senior/Sole Pastor's Ordination
Experience with Woman Clergy

$\begin{array}{lll}\text { Woman } & \text { Woman } & \text { No } \\ \text { Clergy } & \text { Clergy } & \text { Experience } \\ \text { On Staff } & \text { on Staff } & \text { with Woman } \\ \text { Now } & \text { in Past } & \text { Clergy }\end{array}$
before $1960 \quad 1$

1961-1965 2

1966-1970 1

$1971-1975$

$1976-1980$

$1981-1985$

$1986-1990$

since 1990

1
2
1
1
2
0
2
0

Clergy

$\begin{array}{ll}1 & 2 \\ 3 & 1 \\ 2 & 1 \\ 1 & 1 \\ 1 & 2 \\ 3 & 2 \\ 0 & 0 \\ 2 & 0\end{array}$

The pastors of two congregations in the "No Experience" category were ordained before 1960 and are reaching retirement age. It could be interesting to see if their replacements are also male.

SUMMARY OF CLERGY DATA

All the congregations with three or more paid clergy on staff were in the category which used inclusive 
language some of the time. These congregations also were in the category which currently had a clergy woman on staff. All the congregations which had never had a clergy woman on staff had only one paid pastor.

The presence of unpaid associated clergy seems to have some influence. Sixty percent of the congregations with one or more unpaid associated clergy use inclusive language for God at least some of the time. All of the congregations which never use inclusive language and have no experience with woman clergy have fewer than five unpaid associated clergy.

None of the senior/sole pastors of congregations which currently had a clergy woman on staff had been with that congregation for more than ten years. Both pastors who had been with their current congregation for more than twenty years had had a clergy woman on staff in the past. Significant for this study is that the presence of a clergy woman currently on staff does not mean that the congregation will use inclusive language for God in communal prayer. There were two congregations in the "Never Use" category which currently had a clergy woman on staff.

The year in which the senior/sole pastor was ordained may influence the use of inclusive language for God. Half the pastors of congregations using inclusive language at 
least some of the time were ordained before 1971. Only two of the seven pastors of congregations in the "Never Use" category were ordained before 1971. Four congregations had pastors who were ordained since 1985. All of these use inclusive language at least some of the time. These two observations suggest that use of inclusive language for God may be related to a personal characteristic of the pastor or to training during a specific historical period.

USE OF INCLUSIVE LANGUAGE FOR GOD

My questionnaire contained several questions about the use of inclusive language for God. Preliminary research indicated that there were several aspects of religious activity which talk about and to God. By addressing a specific question to each of these areas, the aim was to gain a clearer picture of the way in which congregations use inclusive language for God. This first of these questions asked about the language used for God in hymnody.

Table 29. Use of Inclusive Language for God in Hymnody by Language Use in Prayer

Language Use in Prayer

$\begin{array}{llcc} & \begin{array}{c}\text { Use Inclusive } \\ \text { Language }\end{array} & \begin{array}{c}\text { Some Use of } \\ \text { Inclusive }\end{array} & \begin{array}{c}\text { Never Use } \\ \text { Inclusive }\end{array} \\ \text { Language } \quad \text { Language } & 1 & 0 \\ \text { Hymns Use Always } & 5 & 10 & 2 \\ \text { Inclusive Sometimes } 4 & 2 & 5 \\ \text { Language Never } & 1 & & \end{array}$


Most of the congregations use the hymnal developed by their denomination. The UCC and Methodist hymnals contain more inclusive language than the others. Many of the pastors in the other denominations indicated that they supplemented their denomination material. This was done by replacing masculine-gendered words in certain hymns (e.g., "Rise up, Ye Saints of God" instead of "Rise up, O Men of God") or by using hymns from another source on occasion. One pastor indicated that special hymns are sometimes written for use by the congregation.

Table 30. Use of Inclusive Language for God in Hymnody by Experience with Woman Clergy

Experience with Woman Clergy Woman Clergy Woman Clergy No Experience on Staff Now on Staff in with Woman $\begin{array}{llrr}\text { Hymns Use Always } & 2 & \text { Past } & \\ & & 3 & 3\end{array}$ Inclusive Sometimes $6 \quad 363$ Language Never $\quad 3 \quad 2 \quad 2$

It may be observed that most of the congregations which do not have experience with a woman pastor on staff use inclusive language for God in their hymnody at least some of the time, while most of the congregations which never use inclusive language for God in their hymnody have had some experience with a woman pastor. There seems to be little relationship between experience with a woman pastor and a congregation's use of inclusive language for God in 
hymnody .

Because the content of the sermon is the least prescribed portion of the worship service and is probably the area in which the pastor has the greatest flexibility in terms of language, the next question in the inclusive language section of the questionnaire asked about the language the pastor used to describe God in sermons.

Table 31. Use of Inclusive Language for God in Sermons by Language Use in Prayer

Language Use

\begin{tabular}{|c|c|c|c|c|}
\hline & $\begin{array}{l}\text { Use Inclu } \\
\text { Language }\end{array}$ & & $\begin{array}{l}\text { Some Use of } \\
\text { Inclusive } \\
\text { Language }\end{array}$ & $\begin{array}{l}\text { Never Use } \\
\text { Inclusive } \\
\text { Language }\end{array}$ \\
\hline Sermons Use & Always & 9 & J & \\
\hline Inclusive & Sometimes & 1 & 6 & \\
\hline Language & Never & 0 & 0 & \\
\hline
\end{tabular}

It may be observed that pastors make greater use of inclusive language for God in their sermons than they do in the language of communal prayer. In fact, all the pastors but one indicated that they use inclusive language for God in their sermons on at least an occasional basis. Thus, even some of those who do not use inclusive language for prayer indicated that they always did so in their sermons. 
Table 32. Use of Inclusive Language for God in Sermons by Experience with Woman Clergy

Experience with Woman Clergy

Sermons Use Inclusive Language

Woman
Clergy
on Staff
Now

Always Sometimes Never

7
4
0

Woman
Clergy
on Staff
in Past
10
1
0

No

Experience with Woman

Clergy
1
6
1

The pastors of the majority of congregations which currently had a woman pastor on staff indicated that inclusive language for God was always used in sermons. All congregations with a woman pastor use inclusive language for God in their sermons at least some of the time. Several of those using inclusive language for their sermons sometimes said they did so if it fit the scriptures for the day. As noted above, only one pastor indicated that inclusive language for God is never used in sermons.

Another area in which inclusive language for God may be used is in the material used for Christian Education. In most of the congregations, formal Christian Education material is used only in educating the children during what is commonly called "Sunday School." Some congregations use specific material for their adult programs as well, while a few had no formal program for children. 
Table 33. Use of Inclusive Language for God in Christian Education Material by Language Use in Prayer

Inclusive

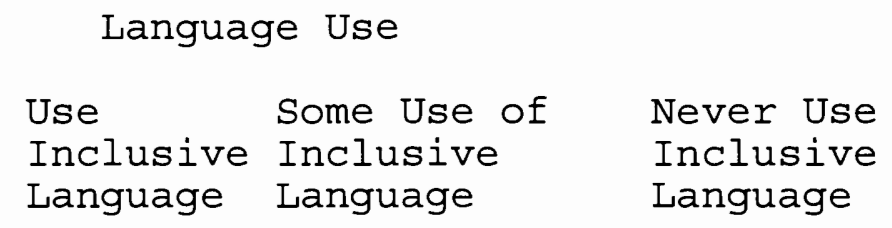

Language in

Christian Always

Education Sometimes 2

Material Never 0

$\begin{array}{lll}8 & 5 & 1 \\ 2 & 4 & 5 \\ 0 & 4 & 1\end{array}$

As could have been predicted, use of inclusive language for God in Christian Education material is strongest among congregations which use it in prayer and less strong among those which use it some of the time. Several of the pastors thought their congregation used their denomination material but seemed unsure about the nature of the language the material used for God. These pastors typically responded that they had assigned responsibility for the Christian Education program to a trusted staff member.

Table 34. Use of Inclusive Language for God in Christian Education Material by Experience with Woman clergy

Experience with Woman Clergy

Woman Clergy Woman Clergy No Experience on Staff Now on Staff in with Woman

Inclusive Past Clergy

Language in Christian Education Always 6 $6 \quad 5$ 3 Material Sometimes 1 $\begin{array}{lll}1 & 3 & 0 \\ 1 & 1 & 1\end{array}$ 0 
As with hymnody, the majority of congregations used their denomination's materials, although several pastors commented that they used Christian Education material from other denominations and a few wrote their own material.

The question about the use of inclusive language for God in of communal prayer has been one of the ways by which the congregations have been grouped in the above tables. Shown in the next table is the way in which the two categories I have been examining relate to each other.

Table 35. Use of Inclusive Language for God in Prayer by Experience with Woman Clergy

$$
\text { Experience with Woman Clergy }
$$

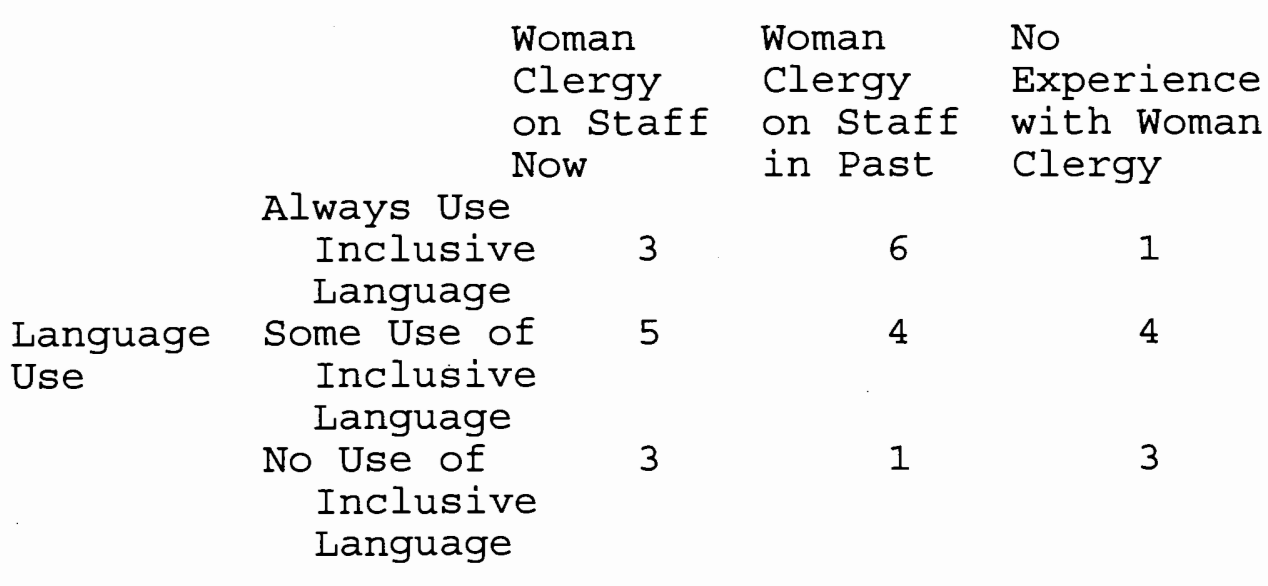

As shown in this table, there is no clear relationship between the congregation's use of inclusive language for God in prayer and its experience with a woman pastor on staff. In answer to this question, one pastor commented that inclusive language for God is always used except for the Lord's Prayer. Another made a point of telling me that inclusive language is used for God but 
they still use masculine language for Jesus.

None of the pastors of congregations currently using inclusive language for God were intending to use it less often. This was true both for congregations in the "Always Use" inclusive language and in the "Some Use" categories. At the other end of the scale, only two of the seven congregations which never use inclusive language were making plans to begin using it. Five of the 13 congregations which use it some of the time were considering using it more often. In general, most of the congregations were intending to continue their current language usage patterns.

Table 36. Intent to Change Use of Inclusive Language for God in Prayer by Language Use

Language Use

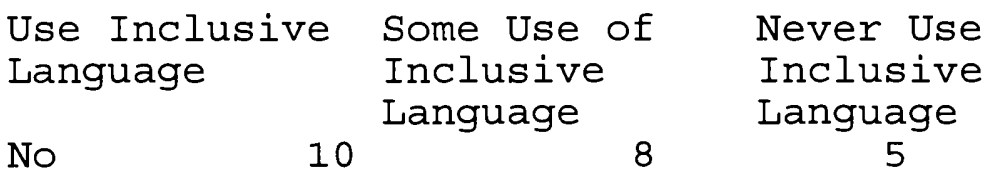

Intent to Change Use of Inclusive Language for Prayer
Use more often Use less often Change time of use Considering changing

0
5 0 0 0
1 0 0 1

The responses are very similar when the congregations are grouped by experience with a woman pastor. Four of the congregations with a woman pastor currently on staff and two of those which have never had a woman pastor were 
planning to increase their use of inclusive language for God in prayer. Two congregations were thinking about increasing usage. One of these currently had a woman pastor and one had had a woman pastor in the past.

Table 37. Intent to Change Use of Inclusive Language for God in Prayer by Experience with Woman Clergy

Experience with Woman Clergy

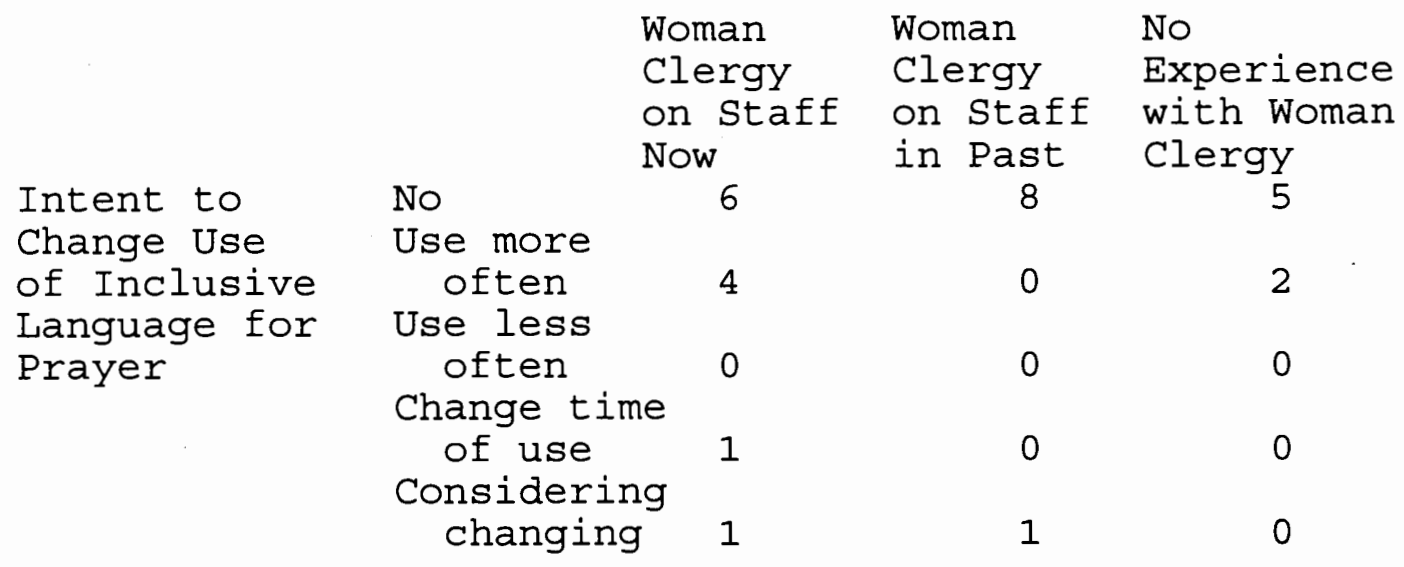

The decision to use inclusive language was made primarily by the pastor, although four indicated that it was the position of the denomination to use it. One noted that the pastor's decision to use inclusive language had been ratified by the board of elders. Another pastor answered that the decision had been made during the tenure of a previous pastor.

Three commented that the decision had resulted jointly from the pastor's decision and the congregation's request. One of these three congregations was in the group currently having a woman pastor, another was in the group which had one in the past, and the third came from a 
congregation which had never had a woman pastor. It should be noted that the requesting congregant may have experienced a woman pastor some where other than in the current congregation.

Table 38. Decision to Use Inclusive Language for God in Prayer by Language Use*

Language Use

Language

Source of Decision to use Inclusive Language for Prayer

Use Inclusive Language

$\begin{array}{lll}\text { Pastor } & 8 & 7 \\ \text { Associate } & & \\ \quad \text { Pastor } & 0 & 2 \\ \begin{array}{ll}\text { Congregation } \\ \text { request }\end{array} & 1 & 1 \\ \text { Denomination } & 2 & 2 \\ \text { Unknown } & 0 & 1\end{array}$

Some Use of Inclusive

*The category, "Never Use Inclusive Language," was omitted from this table.

In most cases the congregation began using inclusive language for God in prayer because the senior or sole pastor wanted to use it. In two congregations, it was the request of the associate pastor which began the usage. In only two cases the use clearly began because of a request from the congregation. This seems to indicate that the pastor is the determinant rather than any experience of the congregation. 
Table 39. Decision to Use Inclusive Language for God in Prayer by Experience with Woman Clergy

Experience with Woman Clergy

Source of Decision to use Inclusive Language for Prayer

Woman
Clergy
on Staff
Now

Pastor

Associate Pastor Congregation request Denomination Unknown
6

1

1

2
Woman Clergy on staff in Past
No Experience with Woman Clergy

$$
2
$$


hymnals than do the other denominations. There appeared to be little relationship between a congregation's experience with a woman pastor and its use of inclusive language for God in hymnody.

All the pastors but one indicated that they used at least some inclusive language for God in their sermons. Most of the congregations which had Christian Education programs used the material produced by their denomination. Use of inclusive language in Christian Education material was highest in the "Use Inclusive Language" category, although one congregation in the "Never" category was in the "Always" category with regard to Christian Education material. This may influence the congregation's language usage in the future as the current cohort of Sunday School children reach adulthood.

The comparison of the categories of experience with woman clergy with categories of language use did not indicate a clear relationship between a congregation's language use and its experience with women clergy. The decision about language usage was made primarily by the pastor and the majority of pastors were intending to continue their current language usage. This seems to indicate that the pastor, rather than the congregation's experience, is the determining factor in language usage. 
LANGUAGE AND EXPERIENCE

When I asked the pastors if they thought the congregation began using inclusive language liturgy as a result of its experience with women clergy, the answers varied widely, from a definite "yes" to an equally definite "no." Most of them fell into a few general categories listed below. Notice that, even though the question asked about why the congregation began using it, many of the pastors responded by giving the reason the pastor began using it.

Probably Yes

I followed a woman in another church and that increased my awareness.

My wife raised my consciousness in seminary when we met.

It's part of the feminist movement in church - more women clergy.

Back in seminary, I was a 70 s feminist.

I read Mary Daly in seminary and had female peers.

Emergence of women clergy created sensitivity to

language, plus a recognition that women in orders can do as well or better than men.

Yes, I became a feminist theologian to deal with my seminary experience.

Not Necessarily

I listened to the pain in people's lives as a result of exclusive language.

It's a justice issue. 
I believe in the liberation movements - race, women it's that natural thing to do.

Both pastors have a justice background and see this as a justice issue.

The congregation has been concerned with language and has provided leadership to the denomination in many areas for 100 years.

\section{$\underline{\text { Probably Not }}$}

Women clergy exposed me to the issue, but were not the cause of my need to be inclusive.

And then there was my favorite, "I have a wife and three older sisters." 
CHAPTER FIVE

SUMMARY AND CONCLUSIONS

This study has examined the possibility that the movement toward the use of inclusive language for God in liturgy by mainstream Protestant Christian denominations in the United States is either the result of changing religious roles for women or that both reflect the larger social change which has taken place since World war II. Inclusive language was defined as language which refers to God in ways that are not exclusively masculine.

The history of women's participation in Christian groups was examined. This was followed by a description of inclusive language and its uses in liturgical settings and an overview of the influence of language on religious thought.

The use of inclusive language for God in liturgical settings was examined in 30 Protestant congregations in the Portland area to examine the use of such language and to compare such usage to the congregations' experience with women clergy.

An analysis of the data indicates that a congregation's experience with women clergy may influence its use of inclusive language for prayer. However, the evidence is not conclusive. The denomination a 
congregation belongs to may be important in determining language use. The United Methodist Church and the United Church of Christ began ordaining women before the other denominations in this study. These two denominations are also producing denomination materials which use inclusive language for God. Denomination materials produced for the Presbyterian, Evangelical Lutheran, and Episcopal churches use more traditional language. Also, these denominations have not been ordaining women for as many years as the UMC and the UCC. This supports the idea that there is a relationship between experience with women clergy and the use of inclusive language for God in communal prayer.

However, experience with woman clergy does not always result in use of inclusive language for God. There were four congregations, three with a woman pastor currently on staff and one with a woman pastor in the past, which made no use of inclusive language for God in prayer. Five congregations having no experience with a woman pastor on staff used inclusive language at least some of the time. On the other hand, the use of inclusive language for God in prayer does not seem to be the direct result of general social change, because the congregations which use it for prayer on either a regular or occasional basis do not seem to be significantly different from those which do 
not use it at all. All three groups are likely to have been influenced by similar change agents. The thirty congregations in this study are all in the same metropolitan area, are members of mainstream denominations which concern themselves with similar issues. The congregations have comparable demographic backgrounds.

The characteristics of the clergy in the congregations studied are quite similar when compared both by language usage and the congregation's experience with women clergy. The only notable exception is the possibility that length of service of the senior or sole pastor in that congregation may have an influence on the pastor's willingness to use inclusive language for public prayer.

Historical scholarship has raised the possibility that there is a relationship between women's religious roles and the society's male/female demographic ratio. It was noted that women had greater freedom to participate during the years immediately following the Civil war in the United States and World War I in Europe. Both of these were periods in which large numbers of young men were killed.

Women's work roles in general, and religious roles specifically, changed during the Second World War because large numbers of young men were in the service. The 
movements which resulted in the ordination of women in the 1950s are related to this. The work force has continued to change since then and may influence the religious roles of women.

The relationships between changing religious roles of women, the movement toward the use of inclusive language for God, and the larger social changes that have taken place since World War II remain unclear.

\section{AREAS FOR FUTURE RESEARCH}

There are a number of areas which may merit further study. One would be to examine John Fowler's stages of faith development to see if there is a relationship between the pastor's faith development and language usage. Research into demographic changes could examine language usage in terms of birth cohort. This would be based on the assumption that the more recent birth cohorts will have had more exposure to the use of various forms of inclusive language than the earlier ones. In addition, more recent birth cohorts will have had greater experience with women in positions of authority, including women clergy .

Another avenue for research would combine demographic data with the idea that the individual's imagery for God develops from early life experience, usually in the 
family. This would examine the possibility that those desiring the use of inclusive language for God share some kind of early experience which has influenced their imagery of God.

\section{CONCLUSION}

The results of this examination are inconclusive. It appears that the movement toward the use of inclusive language in liturgy in mainstream Protestant denominations is not necessarily the result of changing religious roles for women. Rather, both women's ordination and the liturgical movement seem to reflect the larger social changes that have taken place during the second half of the twentieth century. Because the use of inclusive language for God is an area in which there is heated controversy, it merits further study. 
REFERENCES

Alberoni, Francesco. 1984. Movement and Institution. New York: Columbia University Press.

Altizer, Thomas and William Hamilton. 1966. Radical Theology and the Death of God. Indianapolis: BobbsMerrill.

Ashe, Geoffrey. 1976, 1988. The Virgin: Mary's Cult and the Re-Emergence of the Goddess. London, UK: ARKANA.

Berger, Peter L. 1963. A Market Model for the Analysis of Ecumenicity, Social Research 30:7793 . Books.

1967. The Sacred Canopy. Garden City, NY: Anchor

Berger, Peter L. and Thomas Luckmann. 1966. The Social Construction of Reality: A Treatise in the Sociology of Knowledge. Garden City, NY: Doubleday \& Company.

The Bible Gateway, The Holy Bible, Web site URL: <http://www. gospelcom.net/bible?version= RSV\&passage=all>, access date: 6 March 1996.

Black, Alan W. 1988. Organizational Imagery and Interdenominational Mergers. British Journal of Sociology, 41 (1) 105-127.

Boff, Leonardo, OFM. 1987. The Maternal Face of God: The Feminine and Its Religious Expressions. New York: Harper \& Row.

Boldon, Dean A. 1988. Formal Church Polity and Ecumenical Activity. Sociological Analysis, 49. 3:293-303.

Brunner, Peter. 1971. The Ministry and the Ministry of Women. St. Louis, MO: Concordia Publishing House. (German original "Das Hirtenamt und die Frau," appeared in Lutherische Rundschau, Vol. IX, No. 3, 1959).

Christ, Carol P. 1977. "The New Feminist Theology," Religious Studies Review 3:203-12. 
Christ, Carol P. and Judith Plaskow. 1979.

Womanspirit Rising: A Feminist Reader in

Religion. New York: Harper \& Row.

Chung Hyung Kyung. 1993. Re-imagining God, address to REImagining Conference, 5 November, Minneapolis, MN.

The Committee to study the Proper Place of Women, Progress Report to the House of Bishops (Episcopal), October, 1966.

Daly, Mary. 1968. The Church and the second sex. New York, NY: Harper \& Row.

1971. After the Death of God the Father. Commonweal. XCIV, March 12, pp. 7-11. Press.

1973. Beyond God the Father. Boston, MA: Beacon

Douglass, H. Paul. 1934. Church Unity Movements in the United States. New York: Institute of Social and Religious Research.

Durkheim, Emile. 1915. Elementary Forms of the Religious Life. New York: The Free Press.

Field-Bibb, Jacqueline. 1991. Women towards Priesthood: Ministerial Politics and Feminist Praxis. Cambridge, UK: Cambridge University Press.

Geertz, Clifford. 1966. Religion as a Cultural system, in Donald Cutler, ed. The Religious Situation: 1968 . Boston, MA: Beacon Press.

Glock, Charles Y., Benjamin B. Ringer, and Earl R. Babbie. 1966. To Comfort and To Challenge: A Dilemma of the Contemporary Church. Berkeley, CA: University of California Press.

Greeley, Andrew. 1977. The Mary Myth: On the Femininity of God. New York, NY: Seabury press. 1989. Religious Change in America. Cambridge, MA: Harvard University Press.

Harrison, Beverly W. 1984. "Sexism and the Language of Christian Ethics," Making the Connections, Boston: Beacon Press. 
Henly, Nancy M., Mykol Hamilton, and Barrie Thorne.

1983. Womanspeak and Manspeak: Sex Differences and Sexism in Communication, Verbal and

Nonverbal. West Publishing Company.

Heyward, Carter. 1984. Our Passion for Justice: Images of Power, Sexuality, and Liberation. New York, NY: The Pilgrim Press.

Howard, Christian. 1972. The Ordination of Women to the Priesthood: a consultative document presented by the Advisory Council for the Church's Ministry. London, UK: Church Information Office.

Hunt, Mary. 1993. "Sexuality - Family," presentation to RE-Imagining Conference, 5 November, Minneapolis, MN.

Ice, Martha Long. 1987. Clergy Women and Their Worldviews: Calling for a New Age. New York: Praeger.

Lehman, Edward D., Jr. 1985. Women Clergy: Breaking through Gender Barriers. New Brunswick, NJ: Transition Books.

Marshall, Catherine and Gretchen B. Rossman. 1989. Designing Qualitative Research. Newbury Park, CA: Sage Publications, Inc.

McConnell-Ginet, Sally. 1989. The Sexual (Re) Production of Meaning: A Discourse-Based Theory, in Francine Wattman Frank and Paula A. Treichler. Lanquage, Gender, and Professional Writing: theoretical approaches and guidelines for nonsexist usage. New York, NY: Commission on the status of Women in the Profession, The Modern Language Association of America.

Melton, L. Gordon. 1991. Personal Communication. Santa Barbara, California. 22 August.

Noren, Carol M. 1991. The Woman in the Pulpit. Nashville, TN : Abingdon Press.

O'Dea, Thomas F. and Janet O'Dea-Aviad. 1966. The Sociology of Religion. Englewood Cliffs, NJ: Prentice-Hall, Inc. 
Office of Research, Evaluation and Planning of the National Council of the Churches of Christ in the USA. Yearbook of American and Canadian Churches. 1973, 1980, 1985, 1990, 1995, Nashville, TN: Abingdon Press.

Pope John Paul II. 1994. Ordinatio Sacerdotalis. Web site URL : <http://listserv.america.edu/catholic/church/ papal/jpii/jp2ordsa.txts, access date: 6 March 1996.

Ruether, Rosemary Radford. 1975. New Women New Earth: Sexist Ideologies and Human Liberation. New York, NY: Seabury Press.

1983. Sexism and God-Talk. Boston, MA: Beacon Press.

Schussler-Fiorenza, Elisabeth. 1983. In Memory of Her: A Feminist Theological Reconstruction of Christian Origins. New York, NY: Crossroad.

1992. The Twelve and the Discipleship of Equals, in Marie Louis Uhr, ed. Changing Women Changing Church. Newtown, Australia: Millenium Books.

Spretnak, Charlene. 1982. ed. The Politics of Women's Spirituality: Essays on the Rise of Spiritual Power Within the Feminist Movement. Garden City, NY: Anchor Press.

Steering Committee. 1993. RE-Imagining conference material. Minneapolis, MN: RE-Imagining steering Committee.

1994. RE-Imagining newsletter. Minneapolis, MN : RE-Imagining Steering Committee.

Swanson, Guy. 1974. The Birth of the Gods: The Origin of Primitive Beliefs. Ann Arbor, MI: University of Michigan Press.

Tucker, Cynthia, Grant. 1990. Prophetic Sisterhood: liberal women ministers of the frontier, 1880-1930. Boston, MA: Beacon Press.

Uhr, Marie Louise. 1992. Introduction, in Marie Louise Uhr, ed. Changing Women Changing Church. Newtown, Australia: Millenium Books. 
Verdesi, Elizabeth Howe11. 1976. In but still Out: Women in the Church. Philadelphia, PA: The Westminster Press.

Warner, Jody E. and David Hansen. 1994. The Identification and Reporting of Physical Abuse by Physicians: a Review and Implications for Research. Child Abuse and Neglect. Vol. 18:11-25.

Wolfe, David A., Louise Sas, and Christine Wekerle. 1994. Factors Associated with the Development of Posttraumatic Stress Disorder among Child Victims of Sexual Abuse. Child Abuse and Neglect. Vol 18:37-50.

Wuthnow, Robert. 1988. The Restructuring of American Religion: Society and Faith Since World War II. Princeton, NJ: Princeton University Press.

1989. Communities of Discourse: Ideology and Social structure in the Reformation, the Enlightenment, and European Socialism. Boston, MA: Harvard University Press. 
APPENDIX A

The Questionnaire

(Approved by the Portland State University Human Subject

Research Review Committee, May 17, 1993)

INFORMATION ABOUT PERSON FILLING OUT FORM

1. Name/function of person filling out form

2. Length of time in this congregation

3. Length of time in current function

INFORMATION ABOUT CONGREGATION

4. Congregation Name

5. Denomination

- - - - - - above information for researcher only - -

7. Approximate size

$->100 \_100-249-250-500 \_<500$

8. Age Composition

mostly young families __ single adults seniors

mixed _ other (describe)

9. Principal ethnicity

Euro-American Asian-American (describe)
African-American mixed heritage
Hispanic other

10. General education level

few with college education educated mostly college even distribution

11. Income characteristics

2 paycheck families breadwinner/housewife fixed income

12. Income source 
salary/wage
student aid, etc.)

13. Typical occupation

_ labor service _clerical _business

14. Has any of the information in questions 4 through 13 changed during the past 5 years? the past 10 years? If so, in what ways?

\section{INFORMATION ABOUT CLERGY}

15. Number of clergy on staff (paid), full and part-time

16. Number of clergy associated with congregation (not on payrol1)

17. Length of stay of current senior or sole pastor

18. Is this a permanent or interim pastor

19. Who chose current pastor, i.e. congregation or regional deployment

20. Sex of current senior/sole pastor

21. Sex of current assistant pastor(s), if applicable

22. Length of stay of current assistant pastor(s), if applicable

23. Seminary of senior/sole pastor

24. Ordination date of senior/sole pastor

25. Seminary(ies) of assistant (s)

26. Ordination date(s) of assistant(s)

27. Any pervious senior/sole and/or assistant pastors who were female

28. If so, from to 
INFORMATION ABOUT USE OF INCLUSIVE LANGUAGE

29. Is inclusive language used in hymnody

30. Is inclusive language used in sermons

31. Is inclusive language used in Christian education materials

32. Is congregation currently using inclusive language liturgy on a regular basis?

33. If so, how often

34. Are plans being made to change this increase frequency decrease frequency same frequency, different times

35. Does congregation use inclusive language liturgy on occasional basis

36. If so, under what circumstances

37. If used at all, when did the use begin (year)

38. If used, what factors went into the decision to use it senior/sole pastor request liturgy committee request assistant request congregants requested asked to participate in st $\overline{u d y}$ group _other (describe)

39. In your opinion, did the congregation begin using inclusive language liturgy as a result of its experience with women clergy 